\title{
MACROECONOMIC SOURCES OF RISK IN THE TERM STRUCTURE
}

\author{
CHIONA BALFOUSSIA \\ MIKE WICKENS
}

CESIFO WORKING PAPER NO. 1329

CATEgory 5: Fiscal Policy, Macroeconomics AND Growth NOVEMBER 2004

\footnotetext{
An electronic version of the paper may be downloaded

- from the SSRN website: www.SSRN.com

- from the CESifo website: www.CESifo.de
} 


\title{
MACROECONOMIC SOURCES OF RISK IN THE TERM STRUCTURE
}

\begin{abstract}
In this paper we develop a new way of modelling time variation in term premia. This is based on the stochastic discount factor model of asset pricing with observable macroeconomic factors. The joint distribution of excess holding period US bond returns of different maturity and the fundamental macroeconomic factors is modelled using multivariate GARCH with conditional covariances in the mean to capture the term premia. We show how by testing the assumption of no arbitrage we can derive a specification test of our model. We estimate the contribution made to the term premia at different maturities by real and nominal macroeconomic sources of risk. From the estimated term premia we recover the term structure of interest rates and examine how it varies through time. Finally, we examine whether the large number of reported failures of the rational expectations hypothesis of the term structure can be attributed to an omitted time-varying term premium.
\end{abstract}

JEL Code: C5, E4, G1.

Keywords: term structure, the stochastic discount factor model, term premia, GARCH.

\author{
Chiona Balfoussia \\ Department of Economics \\ University of York \\ York, YO1 5DD \\ United Kingdom \\ cb197@york.ac.uk
}

\author{
Mike Wickens \\ Department of Economics \\ University of York \\ York, YO1 5DD \\ United Kingdom \\ mike.wickens@york.ac.uk
}

Financial support for this research was provided by the ESRC, Grant no. R000237862. We would like to express particular thanks to Peter Smith and Steffen Sorensen for their comments and help in the preparation of this paper. 


\section{Introduction}

Historically, the bond market has been of greater concern to macroeconomists than macroeconomics has been to bond market analysts. In macroeconomic explanations of bond prices the emphasis is on the fundamentals whilst the principle of no-arbitrage is often neglected. In contrast, in finance the emphasis is on relative asset pricing rather than fundamentals, but is usually within a no-arbitrage framework. Typically this consists of a time series analysis based on affine latent factor models constrained to satisfy a no-arbitrage condition. Consideration of the fundamentals is usually confined to giving the factors an ex-post ad hoc macroeconomic interpretation. In this paper we attempt to integrate macroeconomics and finance by undertaking a fundamentals analysis of bond prices for US data based on the stochastic discount factor (SDF) model with observable macroeconomic factors. This includes consumption CAPM (C-CAPM), a general equilibrium model of bond pricing, as a special case. The SDF model we use is constrained to be arbitrage free across the term structure.

Our analysis has a number of novel features. We use an SDF model with observable macroeconomic factors instead of the more restrictive, but popular, Vasicek model. We consider three factors: consumption, inflation and output. We carry out the analysis using nominal returns rather than real returns on the grounds that an observable real risk-free rate does not exist. This alters the pricing kernel by including the inflation rate, in addition to consumption. A key feature of our analysis is the use of a multi-variate GARCH model with conditional covariances in the mean of the excess holding period returns. We show that neither univariate GARCH models, nor multi-variate GARCH models without conditional covariances in the mean, are capable of imposing no-arbitrage, and hence, although widely used, are inappropriate.

Apart from estimating the SDF and C-CAPM models, by relaxing some of the assumptions we are able to carry out tests of the no-arbitrage condition. Assuming that the no-arbitrage condition is satisfied in practice, these tests become specification tests of our models. We obtain estimates 
of the term premia for each maturity in each period of time, and we estimate the contribution of each factor in determining the term premia. Having estimates of the term premia enables us to derive point estimates of the yield curve. We are also able to re-examine whether the failure of traditional tests of the rational expectations hypothesis of the term structure are due to omitting the term premia.

The paper is set out as follows. In Section 2 we provide a selective review of the related literature. In Section 3 we provide the theoretical framework for our analysis based on the SDF model. Our econometric methodology modifies the multi-variate GARCH model so that it satisfies a no-arbitrage condition and permits us to obtain point estimates of the time-varying term premia. This is set out in Section 4. The data are described in Section 5. In Section 6 we report our estimates, compare the SDF model with C-CAPM and carry out tests of the no-arbitrage condition. In Section 7 we reconstruct the yield curve using our estimates of the term premia. In this way we can estimate the term structure. In Section 8 we revisit tests of the rational expectations hypothesis of the term structure. Finally, in Section 9 we present our conclusions.

\section{Selective review of related literature}

There is a large body of literature of the empirical evidence on the term structure. Much of the early work was based on the rational expectations hypothesis of the term structure (REHTS) and came to the conclusion that it was rejected by the data. Several possible explanations of this failure have been proposed over the years. ${ }^{1}$ The most fundamental criticism of the REHTS is that it is theoretically incorrect as it assumes that investors are risk neutral, whereas they are well-known to be risk averse. This version of the REHTS (also known as the expectations

\footnotetext{
1 Campbell and Shiller (1991) and Hardouvelis (1994) concluded that long rates over-react to short rates. An alternative opinion, first emphasized by Mankiw and Miron (1986), followed by Hardouvelis (1988) and Rudebusch (1995), and formalized in a theoretical model by McCallum (1994), is that short rates respond to changes in monetary policy. Another strand of the literature relates the failure of the REHTS to "noise traders" and various other forms of irrational expectations of at least some market participants, see Froot (1989), Bekaert, Hodrick and Marshall (1997b).
} 
hypothesis of the term structure) is therefore misspecified due to the omission of a time-varying risk premium. The early studies of Fama (1984), Keim and Stambaugh (1986), Mankiw (1986) and Hardouvelis (1988) supported the significance of time-varying risk premia in bond returns. More recent evidence is by Froot (1989), Fama (1990), Mishkin (1990) and Tzavalis and Wickens (1997). This suggests that omitted variables bias may be the cause of the empirical failure of the REHTS. Unfortunately, the omitted variable - the term premium - is not directly observable, so the solution is not as simple as just including an additional observable variable.

Looking beyond the traditional REHTS literature, there is broad consensus that, in any model of asset pricing, unless risk neutrality is explicitly assumed, a risk premium should be included. From an investor's perspective, risk premia also have substantial informational value. Hence, efforts to correctly model and estimate the risk premium are an integral part of financial research.

Two approaches have been adopted to account for the term premium. One is to find an observable proxy. Modigliani and Shiller (1973), Fama (1976), Mishkin (1982) and Jones and Roley (1983) employed various measures of the variability of interest rates. Shiller, Campbell and Schoenholtz (1983) used a measure of the volume of trade in bonds. Campbell (1987) used a latent variable model of the returns on bills, bonds and common stocks to infer time-varying risk premia in all three markets. Engle, Lilien and Robins (1987) used a time-varying conditional variance of interest rates derived from an ARCH-M model. Simon (1989) used the square of the excess holding-period return to proxy the term premium. Tzavalis and Wickens (1997) found the ex-post holding-period return of one maturity provided a good proxy for the risk premia of other maturities, thereby allowing the yield curve to have a single factor representation. Cochrane and Piazzesi (2001) used a single factor, a tent-shaped function of forward rates to predict one-year excess holding-period returns.

A second, and recently very popular, approach is to specify the term premium based on an appropriate model of the term structure. The usual way to do this is to use the SDF model with latent affine factors, see Campbell (1987), Knez, Litterman and Scheinkman (1994), Gong and 
Remolona (1997), Cochrane and Piazzesi (2001) and Dai and Singleton (2002). Piazzesi (2002) surveys this literature. For a detailed treatment of the SDF model see Cochrane (2001) and Smith and Wickens (2003).

The attraction of affine term structure models is that they provide linear models of yields and term premia. This also means that they are a restricted form of the SDF model. In general, the risk premia implied by the SDF model are captured by the conditional covariances of the excess return over the risk-free rate. In, for example, the Vasicek (1977) and Cox, Ingersoll and Ross (1985) models, two widely-used affine models of bond prices, these conditional covariances are linear functions of the factors. In single factor affine models in general, all bond yields are just a function of the short rate and the shape of the yield curve is fixed through time. Multi-factor affine factor models are more flexible but, arguably, are still over-constrained. Ghysels and Ng (1998) use a semi-parametric framework to test the restrictions imposed by affine term structure models and find that, despite their common use, the empirical evidence does not support them. Duffee (2002) shows that all "completely affine" models of the term structure restrict the variability of the risk premium because they do not allow it to vary independently of interest rate volatility. He proposes a more general class of term structure models he calls "essentially affine", which offer greater flexibility in producing time-varying risk premia. The ability of these models to fit the time variation in conditional variances of yields is however poorer.

Another drawback of latent affine factor models is the difficulty in interpreting the latent factors extracted from the data. Pearson and Sun (1994), for example, labelled their two factors "short rate" and "inflation". In general, such labels are only loose ex-post descriptions. They give only rough guidance on the causes of changes in the shape of the yield curve. On grounds of interpretation, it would be preferable, in principle, to use observations on the short rate and inflation.

Although it is a growing field, to date little work has been done on observable factor models of the term structure. Ang and Piazzesi (2003) estimate a multifactor Vasicek model, allowing 
the SDF model to depend on shocks to both observable and unobservable factors. This model has a VAR structure. They use 3 latent and 2 observable variables (measures of inflation and real activity), and draw on the literature on monetary policy rules to justify their choice of macroeconomic variables. They find that time variation in bond risk premia depend significantly on the macroeconomic factors. Using a New Keynesian macroeconomic model to support the specification of their macroeconomic variables, Rudebusch and Wu (2003) develop and estimate an affine term structure model where the factors are explicit functions of inflation and output. They contrast their macroeconomic factors with the latent factors extracted from an affine latent factor term structure model and find that they are highly correlated. This suggests that the latent factors have macroeconomic underpinnings. Dewachter and Lyrio (2004) draw similar conclusions on the basis of macroeconomic factors and their long run expectations. They find that their model can compete with the three factor latent model, despite the latter's increased flexibility. Finally, Diebold, Rudebusch and Aruoba (2003) find strong evidence of macroeconomic effects on the yield curve. These studies provide considerable support for the use of observable macroeconomic factors in modelling the term structure, but they are not sufficiently informative about precisely what role the factors play in determining bond risk premia.

The advantage of our methodology is that it enables us to obtain estimates of term premia at each point of time, within a no-arbitrage framework, without having to make the restrictive assumptions of previous studies. According to the SDF model, the cause of this time variation is a changing conditional covariation between the factors and the excess holding period returns on bonds. Furthermore, in order to satisfy no-arbitrage, these condition covariances must be present in the conditional mean of the distribution of the excess returns.

A number of implications follow from this. First, the analysis of term premia must be conducted in a multi-variate context as it is necessary to model the joint distribution of the excess holding period returns and the factors. Second, in order to ensure there are no arbitrage opportunities across the term structure, this joint distribution should involve the excess returns at all 
maturities. Third, the conditional covariances must be included in the conditional mean of the joint distribution of excess returns as these are the risk premia. This implies that multi-variate GARCH alone is not adequate as it does not satisfy no arbitrage. Fourth, according to the SDF model, the coefficients of the conditional covariances in the mean are the same for all maturities and are constant across time; time variation in the risk premia is due solely to changing conditional covariances.

This approach was first proposed by Wickens and Smith (2000) for FOREX, and by Smith, Sorensen and Wickens (2003) for equity. For a general survey of the approach see Smith and Wickens (2002). Here, we develop this methodology for application to bond pricing and the term structure. We explicitly price US bonds with reference to their exposure to fundamental sources of macroeconomic risk. Our choice of factors is motivated from the consumption-based intertemporal capital asset pricing model of Rubinstein (1976) and Lucas (1978). We estimate the contribution made to the term premia at different maturities by real and nominal macroeconomic sources of risk, and explicitly test the assumption of no-arbitrage in the US bond market. The time-variation in our term premia has an intuitive interpretation which can be related to the macroeconomic events and policies of the period. From the estimated term premia we recover the term structure of interest rates. Finally, we re-examine whether, by including our estimates of the term premia, it is possible to account for the lack of empirical support for the REHTS.

\section{Theoretical framework}

\subsection{Basic concepts}

We use the following notation. $P_{n, t}=$ price of an $n$-period, zero-coupon (pure discount), defaultfree, bond at $t$, where $P_{0, t}=1$ as the pay-off at maturity is $1 . R_{n, t}=$ yield to maturity of this bond, where the one-period, risk-free rate $R_{1, t}=s_{t} \cdot h_{n, t+1}=$ return to holding an $n$-period bond for one period from $t$ to $t+1$. It follows that

$$
P_{n, t}=\frac{1}{\left[1+R_{n, t}\right]^{n}}
$$


and

$$
R_{n, t} \simeq-\frac{1}{n} \ln P_{n, t}
$$

Thus

$$
\begin{aligned}
1+h_{n, t+1} & =\frac{P_{n-1, t+1}}{P_{n, t}} \\
& =\frac{\left(1+R_{n-1, t}\right)^{-(n-1)}}{\left(1+R_{n, t}\right)^{-n}}
\end{aligned}
$$

And if $p_{n, t}=\ln P_{n, t}$ then taking $\operatorname{logs}$

$$
h_{n, t+1} \simeq p_{n-1, t+1}-p_{n, t}=n R_{n, t}-(n-1) R_{n-1, t+1}
$$

In the absence of arbitrage opportunities, after adjusting for risk, investors are indifferent between holding an $n$-period bond for one period and holding a risk-free 1-period bond. In the absence of default, the risk is due to the price of the bond next period being unknown this period.

$$
E_{t}\left[h_{n, t+1}\right]=s_{t}+\rho_{n, t}
$$

where $\rho_{n, t}$ is the risk, or term, premium on an $n$-period bond at time $t$.

\subsection{SDF model of the term structure}

The SDF model relates the price of an $n$-period zero-coupon bond in period $t$ to its discounted price in period $t+1$ when it has $n-1$ periods to maturity. Thus

$$
P_{n, t}=E_{t}\left[M_{t+1} P_{n-1, t+1}\right]
$$

where $M_{t+1}$ is a stochastic discount factor, or pricing kernel. It follows that

$$
E_{t}\left[M_{t+1}\left(1+h_{n, t+1}\right)\right]=1
$$

and for $n=1$,

$$
\left(1+s_{t}\right) E_{t}\left[M_{t+1}\right]=1
$$

If $P_{n, t}$ and $M_{t+1}$ are jointly log-normally distributed and $m_{t+1}=\ln M_{t+1}$ then

$$
p_{n, t}=E_{t}\left(m_{t+1}\right)+E_{t}\left(p_{n-1, t+1}\right)+\frac{1}{2} V_{t}\left(m_{t+1}\right)+\frac{1}{2} V_{t}\left(p_{n-1, t+1}\right)+\operatorname{Cov}_{t}\left(m_{t+1}, p_{n-1, t+1}\right)
$$


and as $p_{o, t}=0$,

$$
p_{1, t}=E_{t}\left(m_{t+1}\right)+\frac{1}{2} V_{t}\left(m_{t+1}\right)
$$

Subtracting (3) from (2) and re-arranging gives the no-arbitrage equation

$$
E_{t}\left(p_{n-1, t+1}\right)-p_{n, t}+p_{1, t}+\frac{1}{2} V_{t}\left(p_{n-1, t+1}\right)=-\operatorname{Cov}_{t}\left(m_{t+1}, p_{n-1, t+1}\right)
$$

This can be re-written in terms of yields as

$$
-(n-1) E_{t}\left(R_{n-1, t+1}\right)+n R_{n, t}-s_{t}+\frac{(n-1)^{2}}{2} V_{t}\left(R_{n-1, t+1}\right)=(n-1) \operatorname{Cov}_{t}\left(m_{t+1}, R_{n-1, t+1}\right)
$$

and, since $h_{n, t} \simeq n R_{n, t}-(n-1) R_{n-1, t+1}$, as

$$
E_{t}\left(h_{n, t+1}-s_{t}\right)+\frac{1}{2} V_{t}\left(h_{n, t+1}\right)=-\operatorname{Cov}_{t}\left(m_{t+1}, h_{n, t+1}\right)
$$

This is the fundamental no-arbitrage condition for an $n$-period bond ${ }^{2}$. It must be satisfied simultaneously for all maturities to ensure that there are no arbitrage opportunities across the term structure. The term on the right-hand side is the term premium and $\frac{1}{2} V_{t}\left(h_{n, t+1}\right)$ is the Jensen effect. Comparing equations (1) and (5), we note the SDF model implies that

$$
\rho_{n, t}=-\frac{1}{2} V_{t}\left(h_{n, t+1}\right)-\operatorname{Cov}_{t}\left(m_{t+1}, h_{n, t+1}\right)
$$

Empirical work on the term structure can be distinguished by the choice of $\rho_{n, t}$ and the discount factor $m_{t}$. The expectations hypothesis, which is the basis of most tests of the REHTS, assumes that $\rho_{n, t}=0$ but the evidence cited earlier rejects this assumption.

To complete the specification, it is necessary to specify $m_{t}$, the logarithm of the pricing kernel. Assuming joint log-normality of the excess returns and the factors, $m_{t}$ is a linear function of the stochastic discount factors $z_{i t}$

$$
m_{t+1}=a+\sum_{i} \beta_{i} z_{i, t+1}
$$

\footnotetext{
${ }^{2}$ Arbitrage opportunities are excluded if and only if there exists a positive stochastic discount factor $M_{t+1}$ that prices all assets (Cochrane 2001). In the models described in this section, a positive discount factor is used to price bonds of all maturities.
} 
The resulting no-arbitrage condition for the SDF model is

$$
E_{t}\left(h_{n, t+1}-s_{t}\right)+\frac{1}{2} V_{t}\left(h_{n, t+1}\right)=-\sum_{i} \beta_{i} \operatorname{Cov}_{t}\left(h_{n, t+1}, z_{i, t+1}\right)
$$

Although the SDF model places no restrictions on the coefficients of the conditional covariances, it does restrict the coefficient on the conditional variance.

\subsection{General equilibrium models of the term structure}

The SDF model does not specify which factors should be used. They can be latent or observable. An advantage of general equilibrium models of asset pricing is that they do specify the factors. The most widely-used general equilibrium asset pricing model is the C-CAPM based on power utility. This gives a single factor SDF model with real consumption as the factor, and it implies a constant coefficient of relative risk aversion $\sigma$.

C-CAPM is usually expressed in real terms. This involves the use of the excess return and hence assumes the existence of a real risk-free rate. Since, in practice, only a nominal risk-free rate exists (assuming no default risk), we carry out our analysis in nominal terms. This implies two factors: real consumption and inflation. It can be shown that for nominal returns ${ }^{3}$

$$
m_{t+1}=\theta-\sigma \Delta c_{t+1}-\pi_{t+1}
$$

where $m_{t}=$ the $\log$ stochastic discount factor, $c_{t}=\log$ real consumption and $\pi_{t}=$ inflation.

The resulting no-arbitrage condition is, see Smith and Wickens (2002) and Smith, Sorensen and Wickens (2003),

$$
E_{t}\left(h_{n, t+1}-s_{t}\right)+\frac{1}{2} V_{t}\left(h_{n, t+1}\right)=\sigma \operatorname{Cov}_{t}\left(h_{n, t+1}, \Delta c_{t+1}\right)+\operatorname{Cov}_{t}\left(h_{n, t+1}, \pi_{t+1}\right)
$$

We note again that the coefficients in the no-arbitrage condition are the same for all maturities.

\footnotetext{
3 The familiar solution of this intertemporal optimisation problem, in a nominal setup, is the Euler equation $E_{t}\left[\frac{\beta U_{t+1}^{\prime}}{U_{t}^{\prime}} \frac{P_{t}}{P_{t+1}}\left(1+r_{t+1}\right)\right]=1$, where $U_{t}$ is the single-period utility function derived from consumption and $P_{t}$ is the price level at time $t$. The nominal discount factor implied by the C-CAPM is hence: $M_{t+1}=\frac{\beta U_{t+1}^{\prime}}{U_{t}^{\prime}} \frac{P_{t}}{P_{t+1}}$.
} 
A generalisation of C-CAPM is to allow utility to be time non-separable. Smith, Sorensen and Wickens (2003) show that for the Epstein-Zin (1979) utility function the no-arbitrage condition can be written as

$$
E_{t}\left(h_{n, t+1}-s_{t}\right)=\beta_{1} V_{t}\left(h_{n, t+1}\right)+\beta_{2} \operatorname{Cov}_{t}\left(h_{n, t+1}, \Delta c_{t+1}\right)+\beta_{3} \operatorname{Cov}_{t}\left(h_{n, t+1}, \pi_{t+1}\right)
$$

The $\beta_{i}$, which are the same for all maturities, are functions of the deep structural parameters of the general equilibrium model; $\beta_{2}$ is now no longer equal to $\sigma$. This formulation removes a number of the restrictions of C-CAPM with power utility.

\section{Econometric methodology}

\subsection{Estimation}

Our aim is to estimate the no-arbitrage condition either jointly for all maturities, in order to impose no-arbitrage across the term structure, or separately for each maturity, in order to test the no-arbitrage condition. In other words, we must model the joint distribution of the excess holding-period returns jointly with the macroeconomic factors in such a way that the mean of the conditional distribution of each excess holding-period return in period $t+1$, given information available at time $t$, satisfies the no-arbitrage condition. The conditional mean of the excess holdingperiod return involves selected time-varying second moments of the joint distribution. We therefore require a specification of the joint distribution that admits a time-varying variance-covariance matrix. A convenient choice is the multivariate GARCH-in-mean (MGM) model. For a review of multivariate GARCH models see Bollerslev, Chou and Kroner (1997), and see Flavin and Wickens (1998) for a discussion of specification issues for their use in financial models.

Let $\mathbf{x}_{t+1}=\left(h_{n_{1}, t+1}-s_{t}, h_{n_{2}, t+1}-s_{t}, \ldots, z_{1, t+1}, z_{2, t+1}, \ldots\right)^{\prime}$, where $z_{1, t+1}, z_{2, t+1}, \ldots$ include the macroeconomic variables that give rise to the factors in the SDF model through their conditional covariances with the excess holding-period returns. In principle, they may also include additional variables that are jointly distributed with these macroeconomic variables as this may improve the 
estimate of the joint distribution. The MGM model can then be written

$$
\mathbf{x}_{t+1}=\boldsymbol{\alpha}+\boldsymbol{\Gamma} \mathbf{x}_{t}+\mathbf{B g}_{t}+\varepsilon_{t+1}
$$

where

$$
\begin{gathered}
\varepsilon_{t+1} \mid I_{t} \sim D\left[0, \mathbf{H}_{t+1}\right] \\
\mathbf{g}_{t}=\operatorname{vech}\left\{\mathbf{H}_{t+1}\right\}
\end{gathered}
$$

The vech operator converts the lower triangle of a symmetric matrix into a vector. The distribution is the multivariate log-normal distribution. If there are $K$ maturities (excluding the short rate) then the first $K$ equations of the model are restricted to satisfy the no-arbitrage condition.

It will be noted that the theory requires the macroeconomic variables to display conditional heteroskedasticity. This is not something traditionally assumed in macroeconometrics, but seems to be present in our data. Ideally, we would like to use high frequency data for asset returns, but very little macroeconomic data are published for frequencies higher than a month, and then only a few variables are available. Although more macroeconomic variables are published at lower frequencies, they tend not to display conditional heteroskedasticity.

Whilst the MGM model is convenient, it is not ideal. First, it is heavily parameterised which can create numerical problems in finding the maximum of the likelihood function due to the likelihood surface being relatively flat, and hence uninformative. Second, asset returns tend to be excessively volatile. Assuming a non-normal distribution such as a $t$-distribution can sometimes help in this regard by dealing with thicker tails. The main problem, however, is not thick tails, but a small number of extreme values. The coefficients of the variance process of the MGM model have a tendency to produce a near unstable variance process in their attempt to fit these extreme values. In principle, a stochastic volatility model, which includes an extra random term in the variance, could capture these extreme values. Unfortunately, as far as we are aware, no multivariate stochastic model with in-mean effects in the conditional covariances has been proposed in the literature. 
The choice of specification of the conditional covariance matrix is a compromise between generality and feasibility. The latter requires that we limit the number of parameters to estimate. Accordingly, our specification of $\mathbf{H}_{t}$ is that of Ding and Engle (1994), the vector-diagonal multivariate GARCH-in-mean

$$
\mathbf{H}_{t}=\mathbf{H}_{0}\left(\mathbf{i i}^{\prime}-\mathbf{a} \mathbf{a}^{\prime}-\mathbf{b b}^{\prime}\right)+\mathbf{a a}^{\prime} * \mathbf{\Sigma}_{t-1}+\mathbf{b b}^{\prime} * \mathbf{H}_{t-1}
$$

where $\mathbf{i}$ is a vector of ones, * denotes element by element multiplication (the Hadamard product) and $\boldsymbol{\Sigma}_{t-1}=\varepsilon_{t-1} \varepsilon_{t-1}^{\prime}$. This is a special case of the diagonal Vech model, in which each conditional covariance depends only on its own past values and on surprises. The restrictions implicitly imposed by this parameterisation of the multivariate GARCH process guarantee positive-definiteness and also substantially reduce the number of parameters to be estimated, thus facilitating computation and convergence. Stationarity conditions are imposed.

First we estimate the whole system as a standard homoskedastic VAR. This gives a consistent estimator of the long-run variance covariance matrix $\mathbf{H}_{0}$. In the subsequent estimation step we constrain $\mathbf{H}_{0}$ to this value. Our sample has 348 observations. The estimation is performed using quasi-maximum likelihood.

\section{Data}

The complete sample is monthly, from January 1970 to December 1998 . Until 1991, the term structure data are those of McCulloch and Kwon. ${ }^{4} \quad 5$ We then use the data extended by Bliss which is based on the same technique. The maturities available are a 6 month, 1 year, 2 year, 5 year and 10 year bond returns. Excess holding-period returns are taken in excess of the one-

\footnotetext{
${ }^{4} \mathrm{McCulloch}$ used tax-adjusted cubic splines to interpolate the entire term structure from data on most of the outstanding Treasury bills, bonds and notes, see McCulloch (1975) and McCulloch and Kwon (1993). These data have been used extensively in empirical work and are considered very "clean", in that they are based on a broad spectrum of government bond prices and are corrected for coupon and special tax effects. Furthermore, spline-based techniques allow for a high degree of flexibility, since individual curve segments can move almost independently of each other (subject to continuity constraints). Hence they are able to accommodate large variations in the shape of the yield curve.

${ }^{5}$ We are not using the complete term structure dataseries available by McCulloch and Kwon because no real personal consumption data was available for earlier dates.
} 
month risk-free rate provided by K. French ${ }^{6} 7$. Essentially, this is the one-month Treasury bill rate. Selected yields are plotted in Figure 9a.

The macroeconomic variables are the month-on-month growth rates of the consumer price index for all urban consumers (CPI) and real total personal consumption (TPC). ${ }^{8}$

Table 1 presents some descriptive statistics for these data which are expressed in annualised percentages. The average yield curve is upward sloping. Average excess holding-period returns are positive for all maturities and increase with time to maturity. Like most financial data, excess holding-period returns exhibit excess skewness and kurtosis, particularly for short maturities. Fitting a univariate $\operatorname{GARCH}(1,1)$ to them indicates there is also significant heteroskedasticity. ${ }^{9}$ Their unconditional variances increase with maturity, as do the absolute unconditional covariances of the excess returns with the macroeconomic variables.

Table 2 reports the unconditional sample correlations. The unconditional correlations of all excess returns with the macroeconomic variables are negative, and for the CPI their absolute values increase monotonically, with maturity. The excess returns are highly correlated, especially at the short end of the yield-curve. For example, the 6-month and 1-year excess returns have a correlation of 0.95 .

\section{Empirical results}

It is important to note that the models are non-linear and, as a result, the coefficient estimates are not independent of the units of measurement. The theory for the SDF model and C-CAPM were developed in absolute terms, but our data are in annualised percentages. Consequently, the

\footnotetext{
${ }^{6}$ In constructing holding-period returns we use the change in $n$-period yields $\Delta R_{n, t+1}$ instead of $R_{n-1, t+1}-R_{n, t}$, since $R_{n-1, t+1}$ is not available. This approximation is very commonplace in the literature, and is likely to be good for medium and long yields. For a discussion on the effects of this approximation see Bekaert, Hodrick and Marshall (1997a).

7 http://mba.tuck.dartmouth.edu/pages/faculty/ken.french/

${ }^{8}$ Data on CPI were obtained from the U.S. Department of Labor's Bureau of Labor Statistics, while consumption data were obtained from the Federal Reserve Bank of St Louis.

${ }^{9}$ Estimation results are available upon request.
} 
coefficient on the own variance of the holding-period return is constrained to be $\frac{1}{2400}$ and not $\frac{1}{2}$; the coefficient of the inflation covariance in the SDF CAPM is constrained to be $\frac{1}{1200}$ and not 1 ; and the coefficient on the consumption covariance should be interpreted as $\frac{1}{1200} \sigma$ and not $\sigma$.

For the sake of brevity, estimates of the covariance structure are not reported. ${ }^{10}$ For all models the ARCH and GARCH coefficients are highly significant for the excess holding-period return equations and for the macroeconomic variables; typically, the $t$-statistics have more than two significant places. The GARCH coefficients are always much larger than the ARCH coefficients, with typical estimates close to 0.9 and 0.3 , respectively. Further, the GARCH parameter shows a tendency to increase with maturity. As a result, the conditional covariance structure of excess holding-period returns depends largely on the lagged conditional covariance matrix, and much less on lagged innovations. In the equations for the macroeconomic variables, the constant and own lagged values are always highly significant.

\subsection{Coefficient estimates}

The coefficient estimates for each model, and for excess returns on bonds of 6 months, $1,2,5$ and 10 years to maturity, are reported in Table 3a, and the likelihood ratio tests are reported in Table $3 b .^{11}$

\subsubsection{C-CAPM}

The estimates in the first row of Table 3a are for C-CAPM, equation (7), constrained to satisfy no arbitrage across the term structure, and hence are the same for all maturities. In practice, as the coefficient for inflation is constrained to unity, this implies that only one parameter is estimated in the entire system of equations, namely the coefficient of relative risk aversion $\sigma$. The estimate of the coefficient on the consumption covariance is -0.072 and is significant at conventional levels.

\footnotetext{
10 These are available upon request.

11 The same estimations have been performed for systems of smaller dimensions, using a number of different combinations of holding period returns. The statistical significance and the explanatory power of the model vary very little, while the signs of the estimated coefficients and the trends along the yield curve are almost identical for all other combinations we examined.
} 
It implies an estimate of $\sigma$ of 86.4. Like most estimates of the coefficient of relative risk aversion in the literature, this is implausibly large. Based on a likelihood ratio test, from Table $3 \mathrm{~b}$ we note that the consumption covariances of all maturities are also jointly significant. This implies that the term premia are significant. The explanatory power of the model is very low (see Table 3a, columns 11 to 15). This suggests that the dominant components of the excess holding-period returns are innovations in the price of bonds.

\subsubsection{SDF model}

The SDF model, equation (6), is less restrictive than C-CAPM. It is obtained by relaxing the constraint on the coefficient of inflation and dropping the interpretation of the coefficient of the conditional covariance of consumption as the coefficient of relative risk aversion. We continue to impose the no-arbitrage condition across the term structure by constraining the estimates to be the same for all maturities. Estimates of the SDF model are in the second row of Table 3a.

The estimate of the coefficient on the consumption covariance is -0.057 , but is not significant at the $5 \%$ level. Were we still able to interpret the coefficient as for C-CAPM, this would imply

an estimate of $\sigma$ of 68.7 . The estimate of the coefficient of the inflation covariance has switched sign; it is -0.153 and is highly significant. This is very far from its theoretical value of unity under C-CAPM, to which it was previously constrained. From Table 3b, the conditional covariances are jointly significant in the conditional mean of the excess returns. Comparing C-CAPM with the SDF model, a likelihood ratio test of the C-CAPM restrictions strongly rejects them in favour of the more general SDF model. Nevertheless, the explanatory power of the SDF model is also very low.

\subsubsection{Arbitrage models}

We now relax the restrictions that impose no arbitrage on the system. We do this in three ways. First we allow the coefficient on the inflation covariance to differ across maturities; second we allow the coefficient on the consumption covariance to differ across maturities; third we allow 
both coefficients to differ across maturities. The exact specifications of these models are given in the footnote to Table $3 \mathrm{a}$.

The estimates for the first of these models are reported in the third row of Table 3a. An entirely different picture now emerges. The coefficient on the inflation covariance has changed considerably. For the shortest maturity it is 0.424 , even further from the theoretical value implied by C-CAPM. The coefficient estimates decline in absolute size and significance as the time to maturity of the holding-period returns increases, but all are highly significant. The consumption covariance coefficient has now switched sign compared with the two no-arbitrage models. The absolute value of the coefficient is greater, but is insignificant. The explanatory power of the model has increased dramatically compared with the no-arbitrage models. $14 \%$ of the variance of the excess holding-period return is explained for the shortest bond, $7 \%$ is explained for the medium-term bond and $2 \%$ for the longest bond.

The estimates for the second model are reported in the fourth row of Table $3 \mathrm{a}$. The explanatory power of this model is also higher than that of the no-arbitrage models. The results for relaxing the coefficient on the consumption covariance are similar to those for relaxing the inflation covariance. $12 \%$ of the variance of the excess holding-period return is explained for the shortest bond and $5 \%$ is explained for the longest bond. Both the inflation and the consumption coefficients are significant.

The estimates after removing both sets of restrictions are reported in row 5 of Table 3a. The coefficients on the inflation covariance are once again highly significant for all maturities, whereas those for consumption are now significant only at the short end of the yield curve.

Likelihood ratio test statistics for the hypothesis of no-arbitrage against that of arbitrage are reported in Table 3b. Both C-CAPM and the no-arbitrage version of the SDF model are rejected against each of the arbitrage models. These results can be interpreted to mean either that there are in fact arbitrage opportunities across the term structure, or that the models are misspecified as in fact there are no arbitrage opportunities. The latter seems more plausible. These findings suggest 
that testing whether or not the no-arbitrage condition holds provides a valuable new specification test for asset pricing models that involve more than one risky asset. Certainly, just imposing no-arbitrage, as is common in empirical work on the term structure, may hide the inadequacies of a model.

Although we reject the no-arbitrage condition, our results show that macroeconomic variables are significant sources of risk in the term structure. Inflation risk appears to be very strongly priced across the yield curve. These findings support those of Ang and Piazzesi (2004) and Dewachter, Lyrio and Maes (2001) who also find that macroeconomic factors are an important source of variation in bond risk premia.

Another finding is that the coefficient estimates tend to be larger and much more significant at the short end of the term structure than for the longest maturities. These results suggest that investors are better informed about risk at shorter than longer time horizons. Consequently, we would expect term premia to be adjusted more often, and hence to be more volatile, at short horizons than at longer horizons. This conclusion is similar to those of Dewachter and Lyrio (2004) who find that their observable macroeconomic factors are important for modelling the shorter end of the yield curve, while long-run inflation expectations are the prime determinant of the risk premium for longer maturities.

\subsection{Estimated Term Premia}

We now consider the implications of our estimates for the term premia of excess holding period returns. We are interested in the variation in the term premia over time and across maturities, and in the relative contributions of inflation and consumption. We use the most general model in these calculations even though it does not satisfy the no-arbitrage condition. This corresponds to the last row of Table $3 \mathrm{a}$.

As the coefficient estimates for all maturities are negative for the inflation covariance and positive for the consumption covariance, and as the unconditional (i.e. average long-run) correlations 
between the excess returns at all maturities and inflation and consumption are negative in Table 2, we may infer that in general inflation makes a positive contribution to the term premia and consumption makes a negative contribution. We also note that whereas the coefficients for inflation are highly significant, those for consumption are not significant for longer maturities. This suggests that inflation will be the dominant factor determining the term premia and consumption will contribute little. This is precisely what we observe in Figure 1 where we plot the estimated time-varying term premia (plus Jensen effect) for each maturity. Table 4 gives summary statistics for the estimated risk premia. The total term premium is positive in nearly every period and this is due almost entirely to inflation risk. The contribution of consumption risk is very small and the "incorrect" sign of the consumption coefficient has hardly any effect.

An idea of the importance of the term premia relative to the (scaled) excess holding-period return may be obtained from Figure 2. We note that investors required an abnormally large term premium during the 1979-82 period when the Fed was conducting its "monetary experiment" of strict money-base targeting. This led to high and volatile short rates and was accompanied by high and volatile inflation and a US recession. It might therefore be reasonable to expect that both real and nominal factors would contribute to the term premium during this period. It is however the inflation risk premium that dominates. Term premia are also relatively high in the early 1970's, during the first oil crisis, and throughout the 1980's. In both periods inflation volatility was still relatively high. The 1990's was a decade of macroeconomic stability and low inflation (the Greenspan era). Term premia are much lower and more stable as a result.

A comparison of the term premia for different maturities may be made from Figure 3. We find that the term premia increase in magnitude with maturity. Since the coefficients of the conditional covariances decline in absolute value as the time to maturity increases, the size of the term premia may be attributable to the magnitude of the conditional covariances. This finding supports the conclusions of McCulloch (1987) and Wickens and Tzavalis (1997) who found that risk premia increase with maturity, but at a decreasing rate. Heston's (1992) conjecture that risk premia 
for excess holding-period returns of different maturities are related to each other also finds some support here, as the estimated risk premia seem to follow a similar pattern for all maturities and they are highly correlated with each other, see Table 5.

We also find that the explanatory power of the model decreases with maturity. This result is consistent with Ang and Piazzesi (2001) who find that their two macroeconomic factors primarily explain movements at the short end and middle of the yield curve, while their unobservable factors account for most of the movement at the long end. This suggests that additional factors might be needed in our model. Earlier, using survey data, Froot (1989) had found that the failure of the REHTS at the short end of the yield curve is due primarily to a time-varying risk premium, while at the very long end the principal reason is expectations error.

Although the results are not reported, we experimented with different definitions of consumption and with additional variables in the SDF model. We found that using retail sales instead of total personal consumption allowed us to explain a maximum of $13 \%$ of the variance of the excess holding-period returns on the shortest bond; using personal consumption on non-durables and services gave similar results. We conclude from this that there is little to choose between the alternative measures of consumption. Using industrial production as the real factor, gave poorer results than consumption.

\section{Reconstructing the yield curve}

In this section we consider the risk premia embedded in the yields to maturity. We call these the rolling risk premia. This enables us to reconstruct the whole yield curve. One advantage of obtaining point estimates of time-varying term premia (rather than estimating the model using GMM as many studies of the term structure have done) is that we can estimate the yield curve. First we discuss how the risk premia in the yields can be estimated from the term premia. 


\subsection{Estimating the rolling risk premia}

The no-arbitrage equation for an $n$-period bond can be re-expressed as

$$
E_{t}\left[h_{n, t+1}\right]=n R_{n, t}-(n-1) E_{t}\left[R_{n-1, t+1}\right]=s_{t}+\rho_{n, t}
$$

Hence,

$$
(n-1)\left[E_{t}\left[R_{n-1, t+1}-R_{n, t}\right]=\left(R_{n, t}-s_{t}\right)-\rho_{n, t}\right.
$$

where $R_{n, t}-s_{t}$ is the term spread and

$$
\rho_{n, t}=-\frac{1}{2}(n-1)^{2} V_{t}\left(R_{n-1, t+1}\right)-(n-1) \operatorname{Cov}_{t}\left(m_{t+1}, R_{n-1, t+1}\right)
$$

It follows that

$$
\begin{aligned}
R_{n, t} & =\frac{n-1}{n} E_{t}\left[R_{n-1, t+1}\right]+\frac{1}{n}\left(s_{t}+\rho_{n, t}\right) \\
& =\frac{1}{n} \sum_{i=0}^{n-1} E_{t}\left[s_{t+i}+\rho_{n-i, t+i}\right] \\
& =\frac{1}{n} \sum_{i=0}^{n-1} E_{t} s_{t+i}+\omega_{n, t}
\end{aligned}
$$

where

$$
\omega_{n, t}=\frac{1}{n} \sum_{i=0}^{n-1} E_{t} \rho_{n-i, t+i}
$$

is the rolling risk premium. Thus the yield to maturity is the average of expected future short rates plus the average risk premium on the bond over the rest of its life, $\omega_{n, t}$.

In order to re-construct yields it is necessary to estimate $\omega_{n, t}$. In principle, this requires having term premia at all maturities. In practice, as only a few yields are observable at any time, we calculate the missing term premia using a linear interpolation of our estimated term premia. We also need estimates of future term premia. We consider two ways of obtaining these. The first uses estimates of the current term premia plus the assumption of static expectations for future term premia. The second uses estimated future term premia plus the assumption of perfect foresight. All calculations are based, as before, on the most general model estimated. 
We consider time-series plots of these two ways of estimating the rolling risk premium for each maturity. Figure 4 is based on static expectations, and Figure 5 is based on perfect foresight. Figure 6 expresses the rolling premia based on static expectations as a percentage of the total yield, and Figure 7 gives the corresponding information based on perfect foresight. Being averages, the rolling premia show much more persistence than the term premia. Otherwise, they reflect previous findings, being highest during the late seventies, the early 1980's, and during the recession of the early 1990's. Tables 6a and 6b present some descriptive statistics for the two sets of rolling premia.

The average estimated rolling risk premium based on static expectations for the 6-month yield during the 1970's is 0.27 (which is $4.3 \%$ of the yield); in the period from 1979-1982 the corresponding figure is $0.92(7.6 \%)$; the average until the end of the 1980 's is $0.20(2.5 \%)$. During the 1990's, a decade associated with low and very stable inflation as well as positive growth rates, estimated rolling risk premia are very low. For 6-month bonds the average is $0.09(1.8 \%)$. The rolling risk premia are larger the longer the time to maturity. On a few occasions our estimates become negative. Sometimes, particularly during the period 1979-1982, they are clearly excessively large. An example is April 1980 when our estimate for the 10 -year bond is $114 \%$ of the actual yield. However, in general, these estimates seem plausible, at least for short and medium term maturities, and are comparable to those found in other studies.

The rolling premia based on perfect foresight are clearly very different from those based on static expectations, particularly in the 1970's. The reason is that they assume that the market anticipates the high term premia of the period of the Fed's "monetary experiment". These estimates are clearly not plausible. This becomes obvious if we reconstruct the yields implied by the estimated rolling premia.

\subsection{Yield curves}

To estimate the yields we combine the estimated rolling term premia with estimates of expected future short rates as in equation (9). Again we consider the use of static expectations and perfect 
foresight, this time for the expected future short rates. Under static expectations, expected future short rates are set equal to the current short rate $s_{t}$. This implies that the shape of the yield curve and of the term structure reflects nothing more than changes in the rolling risk premia at different maturities.

Figures 8 and 9 give actual and estimated yields under static expectations for short rates and term premia, and under perfect foresight, for three maturities: 1-year, 2-year and 10-year bonds. The panels in Figure 8 are for each maturity, while those in Figure 9 are for each type of estimate. The two figures show that yields are better estimated at shorter than longer maturities, and that the assumption of static expectations provides better estimates than that of perfect foresight. The estimation errors for 6-month and 2-year yields based on static expectations are remarkably small. Even for 10-year bonds they are small from 1984 onwards. Perfect foresight does not introduce large errors for 6-month bonds, but for 2-year bonds they are larger. And for 10-year bonds prior to 1984 the errors are huge.

Inflation is well-known to be an important factor affecting short rates. And we have shown inflation volatility is the major factor in term premia. When inflation is low it appears to be both more predictable and to have lower and more predictable volatility. It is in this case that we are able to estimate yields best. The larger estimation errors under perfect foresight suggest that markets are more likely to mis-price bonds when inflation is more volatile.

\section{Testing the REHTS}

We now return to consider the question raised at the beginning of whether the empirical failures of the REHTS are due to the omission of a time-varying risk premium. We can include our estimate of the term premium $\rho_{n, t}$ as an additional observable variable in the model. The model based on returns can be written

$$
h_{n, t+1}=\alpha+\beta s_{t}+\gamma \rho_{n, t}+\varepsilon_{n, t+1}
$$


where $\varepsilon_{n, t+1}$ is a zero-mean disturbance. According to the REHTS $\alpha=0, \beta=1$ and $\gamma=0$. But if a risk premium is in fact present and we have estimated it accurately, then we would expect $\gamma=1$. Alternatively, we can express the model in terms of yields as

$$
(n-1)\left(R_{n-1, t+1}-R_{n, t}\right)=\delta+\mu\left(R_{n, t}-s_{t}\right)+\nu \rho_{n, t}+\epsilon_{n, t+1}
$$

where we expect $\delta=0, \mu=1, v=-1$ and $\epsilon_{n, t+1}=-\varepsilon_{n, t+1}$.

OLS estimates of these equations are reported in Table 7 for each of the five maturities. Columns $a$ and $c$ are estimates of the standard tests of the REHTS without a risk premium, and columns $b$ and $d$ include the estimated risk premium derived from the most general model (the last row of Table 3a). In the models without the risk premium the estimates of $\beta$ are close to unity for each maturity, but those of $\mu$ are not. This is the usual result. The difference is due to the holding-period returns and the short rate in equation (11) being $\mathrm{I}(1)$, or close to $\mathrm{I}(1)$, variables. This results in super-consistent estimates of $\beta$ even if there is a stationary omitted term premium. In contrast, in equation (12), the change in the yield and the term spread are $\mathrm{I}(0)$ variables, and so an omitted stationary term premium is likely to give biased estimates of $\mu$.

Including the risk premium is expected to have little effect on the estimate of $\beta$ but ought in principle to remove the bias in the estimate of $\mu$, if the risk premium is well estimated and provided it is the principal reason for the empirical failure of the REHTS. The results in column $b$ confirm this for equation (11), which is based on holding period returns. The estimate of $\gamma$ is very close to 1 , its theoretical value, and the coefficient of the short rate is close to its theoretical value. These findings provide considerable support for including a risk premium in tests of the REHTS. They also suggest that we can use this test of the REHTS to provide a further diagnostic check on models of the term premia.

The estimates based on equation (12), the term spread equation, are reported in column $d$. The estimate of $\nu$ is not far from its theoretical value of -1 , especially for short and medium maturities. However, the bias in the estimate of $\mu$ appears to have increased for most maturities. 
This suggests that the estimates of the term premia are less accurate at long maturities and as a result the inclusion of time-varying risk premia is not sufficient to provide strong evidence in support of the REHTS based on an equation using the term spread.

\section{Conclusion}

We have shown how it is possible to directly estimate time-varying term premia derived from observable factors, whilst satisfying the condition of no-arbitrage along the yield curve. Based on the stochastic discount factor model, this requires the specification of the joint distribution of excess holding-period returns and observable factors in which the conditional mean of the excess returns is the no-arbitrage condition. Although multivariate GARCH models are widely used in empirical finance, they are rarely specified with conditional covariances in the mean. We show that, in general, this is essential if a no-arbitrage condition is to be satisfied. ${ }^{12}$

This paper is the first application of this methodology to the term structure. We find that the main source of risk at all maturities is nominal risk due to inflation. We also find that consumption is a significant but less important source of risk. Term premia at shorter maturities are better explained than at longer maturities. The time-variation in our term premia can be related in an intutitive way to the macroeconomic events of the period. The magnitude of the term premia tends to increase with maturity due to the size of the conditional covariance of excess holding period returns with inflation, rather than differences in the coefficient of the covariance terms.

We have found that both the SDF model and C-CAPM constrained to satisfy the no-arbitrage condition across the term structure are rejected in favour of separate SDF models for each maturity. An alternative, but less plausible, interpretation is that the data themselves do not satisfy noarbitrage.

We show how it is possible to reconstruct yields, and hence estimate the term structure, by estimating the risk premia embedded in yields from the term premia of excess holding period

\footnotetext{
12 An exception is when a Vasicek model is used, but this has the drawback of not having a time-varying risk premium.
} 
returns. Our estimates seem to be more accurate for the shorter maturities. When inflation is predictable and has low volatility they are also accurate for longer maturities. The larger errors when estimating yields under perfect foresight suggest that markets may be more prone to misprice bonds when inflation is hard to predict and is volatile.

We re-examine whether or not the main cause of the familiar finding of the failure of the rational expectations hypothesis of the term structure is an omitted term premium. Using our estimates of the term premia as proxies we find that for the holding period return model of the REHTS there is strong evidence in favour of the REHTS when a term premium is included. The evidence is weaker when the test is based on a term spread model of the REHTS.

Our conclusion is that this way of modelling the term structure provides a viable alternative to the methods proposed in the literature. It has produced new ways to test theories of the term structure and has cast new light on several familiar issues. It has also thrown up a new puzzle: why the C-CAPM and SDF models do not appear to satisfy the condition of no-arbitrage. The question of whether to emphasise the fundamental macroeconomic sources of risk, possibly at the expense of no arbitrage, or to impose no arbitrage, possibly at the expense of using macroeconomic fundamentals, remains and takes a new twist.

\section{References}

Ang A., Piazzesi M., 2003, "A no-arbitrage vector autoregression of term structure dynamics with macroeconomic and latent variables", Journal of Monetary Economics, 50, 745-787.

Bekaert G., Hodrick R.J., Marshall D.A., 1997a, "On biases in tests of the Expectations Hypothesis of the term structure of interest rates" Journal of Financial Economics, 44, 309-348

Bekaert G., Hodrick R.J., Marshall D.A., 1997b, "Peso problem' explanations for term structure anomalies" Federal Reserve Bank of Atlanta, Working paper 97-13,

Bollerslev T., Chou R.Y., Kroner K.F., 1992, "ARCH modelling in finance: a selective review of the theory and selective evidence" Journal of Econometrics, 52, 5-59 
Campbell J.Y., 1987, "Stock returns and the term structure" Journal of Financial Economics, 18, $373-399$

Campbell J.Y., Shiller R.J., 1984, "A simple account of the behaviour of long-term interest rates" American Economic Review vol.7 issue 2, 44-48

Campbell J.Y., Shiller R.J., 1991, "Yield spreads and interest rate movements: a bird's eye view" Review of Economic Studies, 58, 495-514

Cochrane J.H., 2001 "Asset pricing” Princeton University Press,

Cochrane J.H., Piazzesi M., 2001, "Bond risk premia" manuscript

Cox, J.C., J. Ingersoll, S. Ross, 1985, "A theory of the term structure of interest rates, Econometrica", $53,385-408$.

Dai, Q. and K. Singleton, 2000, "Specification analysis of affine term structure models, Journal of Finance", 55,1943-1978.

Dai Q., Singleton K., 2002, "Term structure dynamics in theory and reality" manuscript

den Haan W.J. 1995, "The term structure of interest rates in real and monetary economies" Journal of Economic Dynamics and Control, 19, (5-7), 909-940

Dewachter H., Lyrio M., 2004, "Macro factors and the term structure of interest rates", manuscript.

Dewachter H., Lyrio M., Maes K., 2001, "Estimation of a joint model for the term structure of interest rates and the macroeconomy", CES Discussion Paper, KULeuven.

Diebold F.X., Rudebusch G.D., Aruoba S.B., 2003, "The Macroeconomy and the Yield Curve: A Nonstructural Analysis", PIER Working Paper No. 03-024

Ding Z., Engle R.F., 2001, "Large scale conditional covariance matrix modelling, estimation and testing" manuscript

Duffee G.R., 2002, "Term premia and interest rate forecasts in affine models Journal of Finance, 57, $1,405-443^{\prime \prime}$

Duffie D., Kan R., 1996, "A yield factor of interest rates" Mathematical Finance, 6, 379-406

Engle R.F., Lilien D.M., Robins R.P. 1987, "Estimating the time-varying risk premia in the term 
structure: the ARCH-M model" Econometrica, 55, (2), 391-407

Evans M.D.D., Lewis K.K., 1994, "Do stationary risk premia explain it all? Evidence from the term structure" Journal of Monetary Economics, 33, 285-318

Fama E.F., 1984, "The information in the term structure" Journal of Financial Economics, 13, 509-528

Fama E.F., 1976, "Inflation uncertainty and expected return on Treasury bills" Journal of Political Economy, 84, 427-448

Fama E.F., 1990, "Term structure forecasts of interest rates, inflation and real returns" Journal of Monetary Economics, 25, 59-76

Fama E.F., Bliss R.R., 1987, "The information in long-maturity forward rates" American Economic Review vol.77, 680-692

Favero C.A., Mosca F., 2001, "Uncertainty on monetary policy and the expectations model of the term-structure of interest rates" Economic Letters, 71, 369-375

Fisher M., Gilles C., 1998, "Around and around: the expectations hypothesis" Journal of Finance, 53, $1,365-383$

Flavin T.J., Wickens M.R., 1998, "A risk management approach to optimal asset allocation" manuscript

Froot K.A., 1989, "New hope for the expectations hypothesis of the term structure of interest rates" Journal of Finance, 44, 283-305

Ghysels E., Ng S., "A semiparametric factor model of interest rates and tests ot the affine term structure" The Review of Economics and Statistics, 80, 4, 535 - 548

Gong, F.F. and E.M. Remolona, 1997, "Two factors along the yield curve", Papers in Money, Macroeconomics and Finance: The Manchester School Supplement, 65, 1-31.

Hardouvelis G.A., 1988, "The predictive power of the term-structure during recent monetary regimes" Journal of Finance, vol.43, issue 2, 339-356

Hardouvelis G.A., 1994, "The term structure spread and future changes in long and short rates in the G7 countries: Is there a puzzle?" Journal of Monetary Economics, 33, 255-283 
Heston S., 1992, "Testing continuous time models of the term structure of interest rates" School of Organisation and Management, Yale University, Working paper

Hsu C., Kugler P., 1997, "The revival of the expectations hypothesis of the US term structure of interest rates" Economic Letters, 55, 115-120

Jones D.S., Roley V.V., 1983, "Rational expectations and the expectations model of the term structure: a test using weekly data" Journal of Monetary Economics, 12, 453-465

Kan R., Zhou G., 1999, "A critique of the stochastic discount methodology" Journal of Finance, 54, $1221-1248$

Keim D.B., Stambaugh R.F., 1986, "Predicting returns in the stock and bond markets" Journal of Financial Economics, 17, 357-390

Knez P., Litterman R., Scheinkman A., 1994, "Explorations into factors explaining money market returns" Journal of Finance, 49, 5, 1861-1882

Longstaff F.A., 2000, "The term structure of very short term rates: New evidence for the expectations hypothesis" Journal of Financial Economics,

Lucas R.E., 1978, “Asset prices in an exchange economy" Econometrica, 46, 1429-1446

Mankiw N.G., 1986, "The term structure of interest rates revisited" Brookings papers on Economic Activity, 1, 61-96

Mankiw N.G., Miron J.A., 1986, "The changing behaviour of the term structure of interest rate" Quarterly Journal of Economics, 101, 211-228

McCallum B., 1994, "Monetary policy and the term structure of interest rates" NBER, Working paper 4938

McCulloch J.H., 1975, "The tax-adjusted yield curve" Journal of Finance 30, 811-30

McCulloch J.H., 1987, "The monotonicity of the term premium" Journal of Financial Economics, 18, $185-192$

McCulloch J.H., Kochin L.A., 2000, "The Inflation Premium Implicit in the U.S. Real and Nominal Term Structures of Interest Rates" "Ohio State University, Working Paper 98-12, revised 9/2000 
McCulloch J.H., Kwon H.C., 1993, "US term structure data, 1947-1991” Ohio State University, Working paper $93-6$

Mishkin F., 1990, "The information in the longer-maturity term structure about inflation" Quarterly Journal of Economics, 55, 815-828

Mishkin F.S., 1982, Monetary policy and short-term interest rates: an efficient markets, rational expectations approach" Journal of Monetary Economics, 37, 63-72

Modigliani F., Shiller R.J., 1973, "Inflation, rational expectations and the term structure of interest rates" Economica, 40, 12-43

Pearson N., Sun T.S., 1994, "Exploiting the conditional density in estimating the term structure: An application to the Cox, Ingersoll and Ross model" Journal of Finance, 54, 1279-1304

Piazzesi M., 2002, "Affine term structure models" forthcoming in the Handbook of Financial Econometrics

Roberds W., Runkle D., Whiteman C.H., 1996, "Resurrecting the term-structure: a daily view of yield spreads and short-term interest rate movements" Journal of Money, Credit and Banking, 28, 34-53

Rubinstein M., 1976, "The valuation of uncertain income streams and the pricing of options" Bell Journal of Economics and Management Science" 7, 407-425

Rudebusch G.D., 1995, "Federal Reserve interest rate targeting, rational expectations and the term structure" Journal of Monetary Economics, 35, 245-274

Rudebusch G.D., Wu T., 2003, "A macro-finance model of the term structure, monetary policy and the economy" FRBSF Working paper 2003-17

Shiller R.J., Campbell J.Y., Schoenholtz K.L., 1983, "Forward rates and future policy: interpreting the term-structure of interest rates" Brookings papers on Economic Activity, 173-217

Simon D.P., 1989, "Expectations and risk in the Treasury bill market: An instrumental variable approach" Journal of Financial and Quantitative Analysis, 24, 357-368

Smith P.N., Sorensen S., Wickens M.R., 2003 "Macroeconomic sources of equity risk" CEPR Discussion Paper no. 4070. 
Smith P.N., Wickens M.R., 2002, "Asset pricing with observable stochastic discount factors" University of York, Working paper 2002/03

Tzavalis E., Wickens M.R., 1997, "Explaining the failures of the term spread models of the rational expectations hypothesis of the term structure" Journal of Money, Credit and Banking, vol.29, no.3, 364380

Vasicek, O., 1977, "An equilibrium characterization of the term structure", Journal of Financial Economics, 5, 177-188.

Wickens M.R., Smith P.N., 2001, "Macroeconomic sources of FOREX risk" University of York, Working paper $2001 / 13$ 


\begin{tabular}{|c|c|c|c|c|c|c|c|c|}
\hline \multicolumn{9}{|c|}{ Table 1: Descriptive Statistics } \\
\hline & & Mean & Median & Maxim um & Minim um & Std. Dev. & Skewness & Kurtosis \\
\hline Risk Free & 1 month & 6.80 & 6.04 & 17.46 & 2.55 & 2.85 & 1.27 & 4.85 \\
\hline \multirow{5}{*}{ 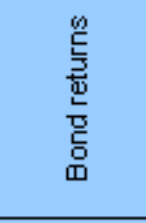 } & 6 months & 7.10 & 6.43 & 16.51 & 2.88 & 2.74 & 1.14 & 4.22 \\
\hline & 1 year & 7.34 & 6.85 & 16.35 & 3.09 & 2.68 & 1.06 & 3.94 \\
\hline & 2 years & 7.64 & 7.07 & 16.15 & 3.80 & 2.52 & 1.07 & 3.85 \\
\hline & 5 years & 8.04 & 7.53 & 15.70 & 4.35 & 2.31 & 1.09 & 3.65 \\
\hline & 10 years & 8.32 & 7.80 & 15.07 & 4.51 & 2.14 & 1.03 & 3.40 \\
\hline \multirow{5}{*}{ 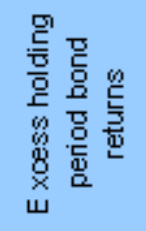 } & 6 months & 0.35 & 0.19 & 24.81 & -14.40 & 3.19 & 1.23 & 15.79 \\
\hline & 1 year & 0.65 & 0.74 & 47.24 & -33.23 & 6.72 & 0.56 & 12.50 \\
\hline & 2 years & 1.07 & 1.02 & 82.48 & -71.01 & 12.60 & 0.20 & 11.30 \\
\hline & 5 years & 1.77 & 2.17 & 111.49 & -128.11 & 26.02 & -0.22 & 6.08 \\
\hline & 10 years & 2.36 & 2.55 & 152.26 & -163.35 & 42.95 & 0.02 & 4.62 \\
\hline \multirow{2}{*}{ 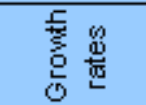 } & $\mathrm{CPI}$ & 5.29 & 4.18 & 23.96 & -5.35 & 4.34 & 1.00 & 4.25 \\
\hline & TPC & 3.52 & 3.35 & 29.87 & -25.59 & 7.16 & 0.14 & 4.76 \\
\hline
\end{tabular}

Niokes

1. Allseries are in annualised percentages.

2. The macroeconomic variables' grounth rates are month-on-month.

\begin{tabular}{|c|c|c|c|c|c|c|c|c|}
\hline \multicolumn{9}{|c|}{ Table 2: Sample Correlations } \\
\hline & & 6 months & 1 year & 2 years & 5 years & 10 years & $\mathrm{CPI}$ & TPC \\
\hline \multirow{5}{*}{ 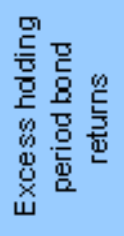 } & 6 months & 1.00 & & & & & & \\
\hline & 1 year & 0.95 & 1.00 & & & & & \\
\hline & 2 years & 0.88 & 0.96 & 1.00 & & & & \\
\hline & 5 years & 0.76 & 0.87 & 0.94 & 1.00 & & & \\
\hline & & 0.67 & 0.76 & 0.84 & 0.94 & 1.00 & & \\
\hline \multirow{2}{*}{ 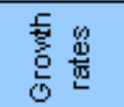 } & $\mathrm{CPI}$ & -0.10 & -0.12 & -0.15 & -0.17 & -0.22 & 1.00 & \\
\hline & TPC & -0.05 & -0.07 & 0.06 & -0.09 & -0.07 & -0.26 & 1.00 \\
\hline
\end{tabular}




\begin{tabular}{|c|c|c|c|c|c|c|c|c|c|c|c|c|c|c|c|}
\hline \multirow{5}{*}{ E stim ation } & Macro & econor & $\begin{array}{l}\text { Bond } \\
\text { mic va }\end{array}$ & $\begin{array}{c}\text { Tabl } \\
\text { maturi } \\
\text { riables }\end{array}$ & $\begin{array}{l}\text { e 3a: E } \\
\text { ties: } 6 \\
\text { CPI I }\end{array}$ & $\begin{array}{l}\text { :stimat } \\
\text { month } \\
\text { nflatio I }\end{array}$ & $\begin{array}{l}\text { ion res } \\
\text { s, 1, 2, } \\
\text { \&. T ot }\end{array}$ & $\begin{array}{l}\text { ults } \\
5 \& 10 \\
\text { al Pers }\end{array}$ & $\begin{array}{l}\text { years } \\
\text { sonal } C\end{array}$ & consun & ption & & & & \\
\hline & \multicolumn{10}{|c|}{ In mean coefficients } & \multicolumn{5}{|c|}{ Explanatory power } \\
\hline & \multicolumn{2}{|c|}{6 months } & \multicolumn{2}{|c|}{1 year } & \multicolumn{2}{|c|}{2 year } & \multicolumn{2}{|c|}{5 year } & \multicolumn{2}{|c|}{10 year } & \multirow{2}{*}{ 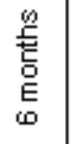 } & \multirow{2}{*}{$\begin{array}{l}\stackrel{5}{\mathbb{9}} \\
\stackrel{2}{ٍ} \\
-\end{array}$} & \multirow{2}{*}{ 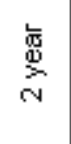 } & \multirow{2}{*}{ 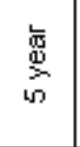 } & \multirow{2}{*}{ 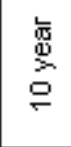 } \\
\hline & $\mathrm{CPI}$ & TPC & $\mathrm{CPI}$ & TPC & $\mathrm{CPI}$ & TPC & $\mathrm{CPI}$ & TPC & $\mathrm{CPI}$ & TPC & & & & & \\
\hline & 1 & 2 & 3 & 4 & 5 & 6 & 7 & 8 & 9 & 10 & 11 & 12 & 13 & 14 & 15 \\
\hline No-arbitrage C-CAPM & 0.001 & $\begin{array}{r}-0.072 \\
-2.18\end{array}$ & 0.001 & $\begin{array}{r}-0.072 \\
-2.18\end{array}$ & 0.001 & $\begin{array}{r}-0.072 \\
-2.18\end{array}$ & 0.001 & $\begin{array}{r}-0.072 \\
-2.18\end{array}$ & 0.001 & $\begin{array}{r}-0.072 \\
-2.18\end{array}$ & 0.00 & 0.00 & 0.00 & 0.00 & 0.00 \\
\hline No-arbitrage SDF & $\begin{array}{r}-0.153 \\
-4.21\end{array}$ & $\begin{array}{r}-0.057 \\
-1.85\end{array}$ & $\begin{array}{r}-0.153 \\
-4.21\end{array}$ & $\begin{array}{r}-0.057 \\
-1.85\end{array}$ & $\begin{array}{r}-0.153 \\
-4.21\end{array}$ & $\begin{array}{r}-0.057 \\
-1.85\end{array}$ & $\begin{array}{r}-0.153 \\
-4.21\end{array}$ & $\begin{array}{r}-0.057 \\
-1.85\end{array}$ & $\begin{array}{r}-0.153 \\
-4.21\end{array}$ & $\begin{array}{r}-0.057 \\
-1.85\end{array}$ & 0.00 & 0.00 & 0.00 & 0.00 & 0.00 \\
\hline Arbitrage 1 & $\begin{array}{r}-0.424 \\
-12.13\end{array}$ & $\begin{array}{r}0.003 \\
0.10\end{array}$ & $\begin{array}{r}-0.415 \\
-10.85\end{array}$ & $\begin{array}{r}0.003 \\
0.10\end{array}$ & $\begin{array}{r}-0.387 \\
-10.32\end{array}$ & $\begin{array}{r}0.003 \\
0.10\end{array}$ & $\begin{array}{r}-0.384 \\
-8.15\end{array}$ & $\begin{array}{r}0.003 \\
0.10\end{array}$ & $\begin{array}{r}-0.298 \\
-7.17\end{array}$ & $\begin{array}{r}0.003 \\
0.10\end{array}$ & 0.14 & 0.10 & 0.07 & 0.04 & 0.02 \\
\hline Arbitrage 2 & $\begin{array}{r}-0.426 \\
-10.73\end{array}$ & $\begin{array}{r}0.109 \\
3.19\end{array}$ & $\begin{array}{r}-0.426 \\
-10.73\end{array}$ & $\begin{array}{r}0.040 \\
1.28\end{array}$ & $\begin{array}{r}-0.426 \\
-10.73\end{array}$ & $\begin{array}{r}0.071 \\
2.05\end{array}$ & $\begin{array}{r}-0.426 \\
-10.73\end{array}$ & $\begin{array}{r}0.067 \\
1.99\end{array}$ & $\begin{array}{r}-0.426 \\
-10.73\end{array}$ & $\begin{array}{r}0.124 \\
2.60\end{array}$ & 0.12 & 0.09 & 0.08 & 0.05 & 0.05 \\
\hline Arbitrage General & $\begin{array}{r}-0.460 \\
-9.44 \\
\end{array}$ & $\begin{array}{r}0.146 \\
3.37 \\
\end{array}$ & $\begin{array}{r}-0.373 \\
-7.09 \\
\end{array}$ & $\begin{array}{r}0.033 \\
0.89 \\
\end{array}$ & $\begin{array}{r}-0.342 \\
-6.62 \\
\end{array}$ & $\begin{array}{r}0.043 \\
1.12 \\
\end{array}$ & $\begin{array}{r}-0.268 \\
-4.37 \\
\end{array}$ & $\begin{array}{r}0.014 \\
0.33 \\
\end{array}$ & \begin{tabular}{|r}
-0.182 \\
-2.79 \\
\end{tabular} & $\begin{array}{r}-0.020 \\
-0.33 \\
\end{array}$ & 0.06 & 0.03 & 0.02 & 0.01 & 0.01 \\
\hline
\end{tabular}

Wioces

1. The excess return equations of the modek es timated are the following:

No-arbitrage C-CAPM: $E_{t}\left(h_{n, i+1}-s_{t}\right)=0.5 \mathrm{~V}_{t}\left(h_{n, i+1}\right)+\beta_{1} \operatorname{Cov} t\left(h_{n, i+1}, \Delta c_{i+1}\right)+\mathrm{COV}_{t}\left(h_{n, i+1}, n_{i+1}\right)$

No-arbitrage SDF: $\quad E_{t}\left(h_{n, t+1}-s_{t}\right)=0.5 V_{t}\left(h_{n, t+1}\right)+\beta_{1} \operatorname{Cov} t\left(h_{n, i+1}, \Delta c_{t+1}\right)+\beta_{2} \operatorname{Cov} t\left(h_{n, t+1}, n_{t+1}\right)$

Arbitrage 1: $\quad E_{t}\left(h_{n, i+1}-s_{t}\right)=0.5 V_{t}\left(h_{n, i+1}\right)+\beta_{7} \operatorname{Cov} t\left(h_{n, i+1}, \Delta c_{i+1}\right)+\beta_{2, n} \operatorname{Cov}_{t}\left(h_{n, t+1}, n_{i+1}\right)$

Arbitrage 2: $\quad E_{t}\left(h_{n, i+1}-s_{t}\right)=0.5 V_{t}\left(h_{n, i+1}\right)+\beta_{i, n} \operatorname{Cov}_{t}\left(h_{n, i+1}, \Delta c_{i+1}\right)+\beta_{2} \operatorname{Cov}_{t}\left(h_{n, t+1}, n_{i+1}\right)$

Arbitrage General: $\quad E_{t}\left(h_{n, i+1}-s_{t}\right)=0.5 V_{t}\left(h_{n, i+1}\right)+\beta_{i, n} \operatorname{Cov} t\left(h_{n, i+1}, \Delta C_{i+1}\right)+\beta_{2, n} \operatorname{CoV}_{t}\left(h_{\left.n, i+1, \pi_{i+1}\right)}\right.$

2. Columrs TPC and CPI report the estimated $\beta_{1}$ and $\beta_{2}$ respectively, for different maturities and models.

3. Since the model is highty non-linear, the estimates are not unit free. For example, for the C-CAPM estimation, the theory implies that the coefficient of the inflation cowariances should be corstrained to 1 . However, all our data are in annualised percentages, for numeric al ease. Subsequently we must instead constrain the coefficient of the inflation covariances to $1^{x}(1 / 1200)=0.001$ as appears above. Convers ely, in the subsequent estiomation which does not restrict the coefficient of the inflation courariances, one can recover the implied value for the raw data by imverting the above calculation: $-0.153^{x} 1200=-183.6$.

4. $t$-statistics are belon the estimated parameters in italics.

5. The explanatory ponver of the model is measured as the share of the variance of the excess holding-period return explained for each maturity.

\begin{tabular}{|c|c|c|c|c|c|}
\hline \multicolumn{6}{|c|}{ Table 3b: Likeliho od ratio tests } \\
\hline Estimation & $\begin{array}{c}\text { Joint } \\
\text { Significance }\end{array}$ & $\begin{array}{c}\text { No-arbitrage } \\
\text { C-C AP M }\end{array}$ & $\begin{array}{l}\text { No-arbitrage } \\
\text { SDF }\end{array}$ & Arbitrage 1 & Arbitrage 2 \\
\hline No-arbitrage $\mathrm{C}-\mathrm{C} A \mathrm{PM}$ & $4.4 * \quad(1)$ & & & & \\
\hline No-arbitrage SDF & $12.1=(2)$ & $7.8=(1)$ & & & \\
\hline Arbitrage 1 & $18.9 *$ & $14.6 *$ & (4) & & \\
\hline Arbitrage 2 & $25.4 \%$ & $21.1 *(5)$ & $13.3=(4)$ & & \\
\hline Arbitrage General & $53.2 *(10)$ & $48.9 * \quad(9)$ & $41.1^{*}$ (8) & $34.3=(4)$ & $27.8^{*} \quad(4)$ \\
\hline
\end{tabular}

ivas

1. The column title corresponds to the null hypothesis tested (the restricted model). The row title corresponds to the alternative hypothesis (the unrestricted model).

2 . \# denotes rejection of the null at the $5 \%$ signific ance level.

3. The first column tests the joint significance of all covariance terms in the estimation.

4. The number of parameter corstraints tested is in parentheses, to the right of the corresponding test statistic. 


\begin{tabular}{|l|ccccc|}
\hline \multicolumn{5}{|c|}{ Table 4: Descriptive statistics of estimated risk premia } \\
\hline & 6 m onths & 1 year & 2 years & 5 years & 10 years \\
\hline Mean & 0.57 & 1.09 & 1.81 & 2.89 & 4.68 \\
Median & 0.32 & 0.78 & 1.34 & 2.21 & 3.74 \\
Maxim um & 5.17 & 6.24 & 11.89 & 13.50 & 15.14 \\
Minim um & -1.43 & -0.36 & -2.57 & -4.07 & -0.18 \\
Std. Dev. & 0.77 & 1.11 & 1.84 & 2.72 & 2.79 \\
Skemness & 2.27 & 2.28 & 2.28 & 1.65 & 1.48 \\
Kurtosis & 10.24 & 8.10 & 8.79 & 5.64 & 4.70 \\
\hline
\end{tabular}

Notes

1. Estimated risk premia from estimation 10 have been used.

\begin{tabular}{|c|ccccc|}
\hline \multicolumn{5}{|c|}{ Table 5: C orrelations of estimated risk premia } \\
\hline & 6 months & 1 year & 2 years & 5 years & 10 years \\
\hline 6 months & 1.00 & & & & \\
1 year & 0.90 & 1.00 & & & \\
2 years & 0.87 & 0.99 & 1.00 & & \\
5 years & 0.72 & 0.91 & 0.94 & 1.00 & \\
10 years & 0.62 & 0.85 & 0.88 & 0.96 & 1.00 \\
\hline
\end{tabular}

Motes

1. Estimated risk premia from estimation 10 have been used. 


\begin{tabular}{|c|c|c|c|c|c|c|}
\hline \multicolumn{7}{|c|}{$\begin{array}{l}\text { Table 6a Reconstructed rolling risk premia and yields } \\
\text { (static expectations) }\end{array}$} \\
\hline Maturities & $\begin{array}{l}\text { Observed } \\
\text { Yields }(A)\end{array}$ & $\begin{array}{l}\text { Reconstructed } \\
\text { Yelds }(\theta)\end{array}$ & $\begin{array}{l}\text { Rolling Risk } \\
\text { Prem ium }\end{array}$ & $\begin{array}{c}\text { Rolling Risk } \\
\text { Premium } \\
(\% \text { of } \mathrm{A})\end{array}$ & $\begin{array}{l}\text { Error } \\
(\text { A-B })\end{array}$ & $\begin{array}{c}\text { Error } \\
\text { (as a } \% \text { of } \mathrm{A})\end{array}$ \\
\hline \multicolumn{7}{|c|}{ Average of period $1970-1998$} \\
\hline 6 months & 7.10 & 7.09 & 0.29 & 4.04 & 0.01 & 0.17 \\
\hline 1 year & 7.34 & 7.38 & 0.58 & 7.93 & -0.04 & -0.53 \\
\hline 2 years & 7.64 & 7.83 & 1.03 & 13.52 & -0.19 & -2.51 \\
\hline 5 years & 8.04 & 8.63 & 1.83 & 22.80 & -0.59 & -7.32 \\
\hline 10 years & 8.32 & 9.88 & 3.08 & 37.02 & -1.56 & -18.72 \\
\hline \multicolumn{7}{|c|}{ Awerage of period 1970-1978 } \\
\hline 6 months & 6.28 & 6.12 & 0.27 & 4.34 & 0.16 & 2.61 \\
\hline 1 year & 6.51 & 6.36 & 0.51 & 7.83 & 0.15 & 2.36 \\
\hline 2 years & 6.72 & 6.66 & 0.82 & 12.14 & 0.05 & 0.81 \\
\hline 5 years & 7.05 & 7.00 & 1.16 & 16.39 & 0.05 & 0.70 \\
\hline 10 years & 7.28 & 7.65 & 1.80 & 24.71 & -0.36 & -5.01 \\
\hline \multicolumn{7}{|c|}{ Average of period 1979-1982 } \\
\hline 6 months & 12.06 & 12.66 & 0.92 & 7.59 & -0.60 & -4.98 \\
\hline 1 year & 12.11 & 13.51 & 1.77 & 14.59 & -1.40 & -11.55 \\
\hline 2 years & 11.98 & 14.79 & 3.04 & 25.36 & -2.80 & -23.39 \\
\hline 5 years & 11.77 & 16.86 & 5.12 & 43.47 & -5.09 & -43.24 \\
\hline 10 years & 11.65 & 19.17 & 7.42 & 63.65 & -7.51 & -64.45 \\
\hline \multicolumn{7}{|c|}{ Average of period 1983-1989 } \\
\hline 6 months & 7.86 & 7.73 & 0.20 & 2.48 & 0.13 & 1.60 \\
\hline 1 year & 8.24 & 8.00 & 0.47 & 5.67 & 0.24 & 2.86 \\
\hline 2 years & 8.73 & 8.47 & 0.94 & 10.74 & 0.25 & 2.91 \\
\hline 5 years & 9.30 & 9.58 & 2.04 & 21.98 & -0.28 & -3.02 \\
\hline 10 years & 9.63 & 11.43 & 3.90 & 40.46 & -1.80 & -18.72 \\
\hline \multicolumn{7}{|c|}{ Average of period 1990-1998 } \\
\hline 6 m onths & 5.10 & 5.06 & 0.09 & 1.84 & 0.05 & 0.92 \\
\hline 1 year & 5.34 & 5.18 & 0.22 & 4.05 & 0.16 & 3.05 \\
\hline 2 years & 5.77 & 5.39 & 0.43 & 7.45 & 0.38 & 6.61 \\
\hline 5 years & 6.39 & 5.84 & 0.88 & 13.73 & 0.55 & 8.55 \\
\hline 10 years & 6.85 & 6.74 & 1.78 & 25.97 & 0.11 & 1.57 \\
\hline
\end{tabular}

Mokes

1. Estimated risk premia from estimation 10 have been used. 


\begin{tabular}{|c|c|c|c|c|c|c|}
\hline \multicolumn{7}{|c|}{$\begin{array}{l}\text { Table 6b: Reconstructed rolling risk premia and yields } \\
\text { (perfect foresight of short rates and risk premia) }\end{array}$} \\
\hline Maturities & $\begin{array}{l}\text { Observed } \\
\text { Yields (A) }\end{array}$ & $\begin{array}{l}\text { Reconstructed } \\
\text { Yields (B) }\end{array}$ & $\begin{array}{l}\text { Rolling Risk } \\
\text { Premium }\end{array}$ & $\begin{array}{c}\text { Rolling R isk } \\
\text { Prem ium } \\
(\% \text { of } A)\end{array}$ & $\begin{array}{l}\text { Error } \\
(\text { A-B) }\end{array}$ & $\begin{array}{c}\text { Error } \\
\text { (as a } \% \text { of } \mathrm{A})\end{array}$ \\
\hline \multicolumn{7}{|c|}{ Average of period 1970-1988 } \\
\hline 6 months & 7.99 & 8.00 & 0.39 & 4.50 & -0.01 & 0.48 \\
\hline 1 years & 8.24 & 8.41 & 0.77 & 8.72 & -0.17 & -1.70 \\
\hline 2 years & 8.50 & 9.06 & 1.34 & 14.89 & -0.56 & -7.35 \\
\hline 5 years & 8.82 & 10.17 & 2.37 & 27.52 & -1.35 & -19.87 \\
\hline 10 years & 9.03 & 11.50 & 3.90 & 46.87 & -2.47 & -36.68 \\
\hline \multicolumn{7}{|c|}{ Average of period 1970-1978 } \\
\hline 6 months & 6.28 & 6.20 & 0.28 & 4.32 & 0.09 & 1.63 \\
\hline 1 years & 6.51 & 6.56 & 0.54 & 8.13 & -0.05 & -0.90 \\
\hline 2 years & 6.72 & 7.34 & 0.97 & 14.06 & -0.62 & -9.47 \\
\hline 5 years & 7.05 & 9.94 & 2.39 & 32.70 & -2.89 & -39.77 \\
\hline 10 years & 7.28 & 13.46 & 4.98 & 68.18 & -6.18 & -85.18 \\
\hline \multicolumn{7}{|c|}{ Average of period $1979-1982$} \\
\hline 6 months & 12.06 & 12.62 & 0.95 & 7.91 & -0.56 & -5.56 \\
\hline 1 years & 12.11 & 13.46 & 1.87 & 15.57 & -1.35 & -13.32 \\
\hline 2 years & 11.98 & 14.45 & 3.06 & 26.19 & -2.46 & -24.73 \\
\hline 5 years & 11.77 & 13.48 & 3.61 & 33.11 & -1.71 & -20.75 \\
\hline 10 years & 11.65 & 12.53 & 4.19 & 37.82 & -0.87 & -11.81 \\
\hline \multicolumn{7}{|c|}{ Average of period 1983-1988 } \\
\hline $6 \mathrm{~m}$ onths & 7.78 & 7.56 & 0.18 & 2.50 & 0.23 & 2.82 \\
\hline 1 years & 8.21 & 7.76 & 0.39 & 5.03 & 0.45 & 4.87 \\
\hline 2 years & 8.79 & 8.00 & 0.72 & 8.59 & 0.79 & 7.35 \\
\hline 5 years & 9.46 & 8.28 & 1.52 & 16.17 & 1.18 & 10.02 \\
\hline 10 years & 9.84 & 7.93 & 2.12 & 21.51 & 1.91 & 18.16 \\
\hline
\end{tabular}

Niokes

1. Estimated risk premia from estimation 10 have been us ed. 


\begin{tabular}{|c|c|c|c|c|}
\hline \multicolumn{5}{|c|}{ Table 7: Tests of the REHTS with and witho ut risk premia } \\
\hline & \multicolumn{2}{|c|}{ Holding-period equation } & \multicolumn{2}{|c|}{ Term spread equation } \\
\hline & $a$ & $b$ & $\mathrm{c}$ & $d$ \\
\hline & \multicolumn{4}{|c|}{ 6-m onth bond } \\
\hline Constant & $\begin{array}{c}-0.183^{\#} \\
-0.24\end{array}$ & $\begin{array}{c}0.415^{\#} \\
0.69\end{array}$ & $\begin{array}{c}-0.173^{\#} \\
-0.83\end{array}$ & $\begin{array}{c}0.332 \\
1.41\end{array}$ \\
\hline Short rate & $\begin{array}{c}1.076= \\
8.47\end{array}$ & $\begin{array}{c}0.904= \\
8.89\end{array}$ & $\begin{array}{c}0.471= \\
1.44\end{array}$ & $\begin{array}{r}0.402 \\
1.33\end{array}$ \\
\hline $\mathrm{R}$ isk P rem ium & & $\begin{array}{c}0.995 * \\
2.08\end{array}$ & & $\begin{array}{c}-0.842= \\
-1.66\end{array}$ \\
\hline Adjusted $R^{2}$ & 0.482 & 0.498 & 0.017 & 0.056 \\
\hline \multicolumn{5}{|c|}{ 1-year bond } \\
\hline Constant & $\begin{array}{c}-0.726^{\#} \\
-0.49\end{array}$ & $0.052=$ & $\begin{array}{c}-0.411^{\#} \\
-0.78\end{array}$ & $\begin{array}{c}0.639 \\
1.06\end{array}$ \\
\hline Short rate & $\begin{array}{c}1.197= \\
4.79\end{array}$ & $\begin{array}{c}0.917 \\
4.47\end{array}$ & $\begin{array}{c}0.632 \\
1.10\end{array}$ & $\begin{array}{c}0.546= \\
1.03\end{array}$ \\
\hline $\mathrm{R}$ isk P rem ium & & $\begin{array}{c}1.029 * \\
1.36\end{array}$ & & $\begin{array}{c}-0.917= \\
-1.27\end{array}$ \\
\hline Adjusted $R^{2}$ & 0.205 & 0.214 & 0.007 & 0.027 \\
\hline \multicolumn{5}{|c|}{ 2-year bond } \\
\hline $\begin{array}{l}\text { Constant } \\
\text { Short rate } \\
\text { R isk P rem ium }\end{array}$ & $\begin{array}{c}-0.838^{\#} \\
-0.32 \\
1.269^{\#} \\
2.89\end{array}$ & $\begin{array}{c}0.458^{*} \\
0.21 \\
0.787= \\
2.00 \\
1.095= \\
1.19\end{array}$ & $\begin{array}{c}-0.537= \\
-0.48 \\
0.457= \\
0.53\end{array}$ & $\begin{array}{c}1.315^{\#} \\
1.07 \\
0.269^{*} \\
0.36 \\
-0.933^{\#} \\
-1.14 \\
\end{array}$ \\
\hline Adjusted $R^{2}$ & 0.074 & 0.084 & -0.001 & 0.014 \\
\hline \multicolumn{5}{|c|}{ 5-year bond } \\
\hline Constant & $\begin{array}{c}1.115^{*} \\
0.23\end{array}$ & $\begin{array}{c}2.647 \\
0.58\end{array}$ & $\begin{array}{c}0.477^{*} \\
0.20\end{array}$ & $\begin{array}{c}2.915 \\
1.30\end{array}$ \\
\hline Short rate & $\begin{array}{c}1.082= \\
1.37\end{array}$ & $\begin{array}{c}0.396 \\
0.50\end{array}$ & $\begin{array}{c}-0.721= \\
-0.55\end{array}$ & $\begin{array}{c}-0.878^{*} \\
-0.73\end{array}$ \\
\hline $\mathrm{R}$ isk P rem ium & & $\begin{array}{c}1.083 \\
1.24\end{array}$ & & $\begin{array}{c}-0.775 * \\
-0.95\end{array}$ \\
\hline Adjusted $R^{2}$ & 0.011 & 0.015 & -0.001 & 0.002 \\
\hline \multicolumn{5}{|c|}{ 10-year bond } \\
\hline Constant & $\begin{array}{c}4.647^{\#} \\
0.62\end{array}$ & $\begin{array}{c}4.223= \\
0.56\end{array}$ & $\begin{array}{c}2.430= \\
0.61\end{array}$ & $\begin{array}{c}4.838= \\
0.95\end{array}$ \\
\hline Short rate & $\begin{array}{c}0.643^{*} \\
0.53\end{array}$ & $\begin{array}{c}0.167^{*} \\
0.13\end{array}$ & $\begin{array}{c}-2.044 \\
-1.14\end{array}$ & $\begin{array}{c}-2.142= \\
-1.25\end{array}$ \\
\hline Risk P remium & & $\begin{array}{c}0.784 \\
0.61\end{array}$ & & $\begin{array}{c}-0.483 \\
-0.41\end{array}$ \\
\hline Adjusted $R^{2}$ & -0.001 & -0.002 & 0.003 & 0.002 \\
\hline
\end{tabular}

Noxes

1. Estimated risk premia from estimation 10 have been used.

2. \# denotes that the hypothes $\mathrm{s}$ of equality to the theoretical value can not be rejected at the $5 \%$ signific ance level.

3. $t$-statistics us ing 'W' hite heterosk edas ticity-consistent standard errors are below the estimated parameters in italics. 
Figure 1: Estimated Risk Premia (including Jensen effect) and their macroeconomic components

a. 6-monthbond

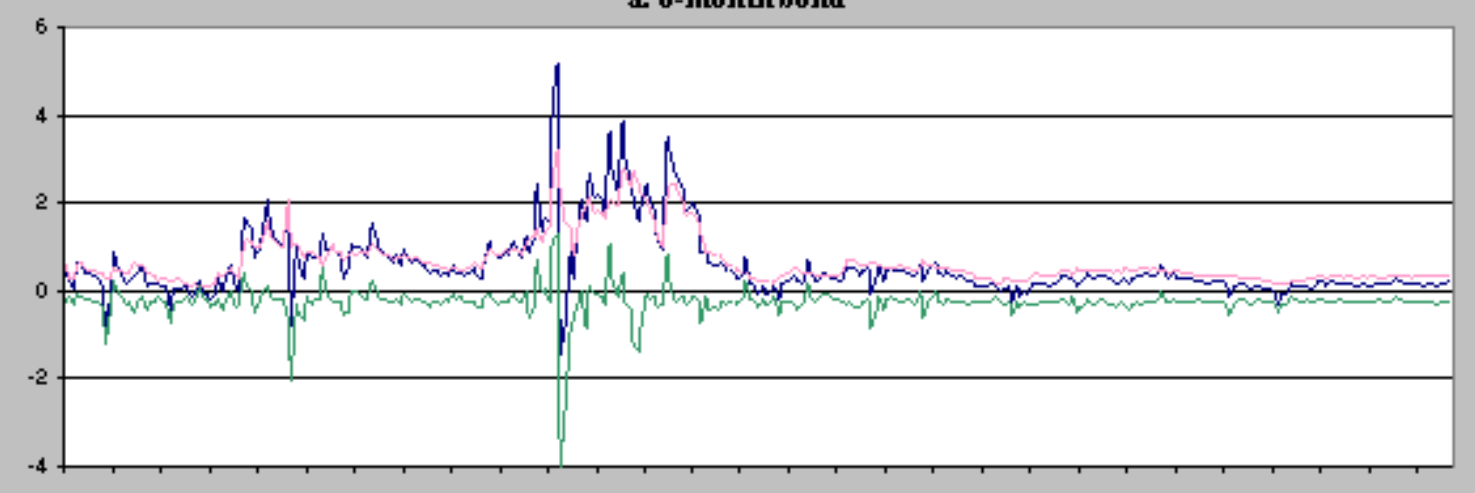

b. 2-year bond

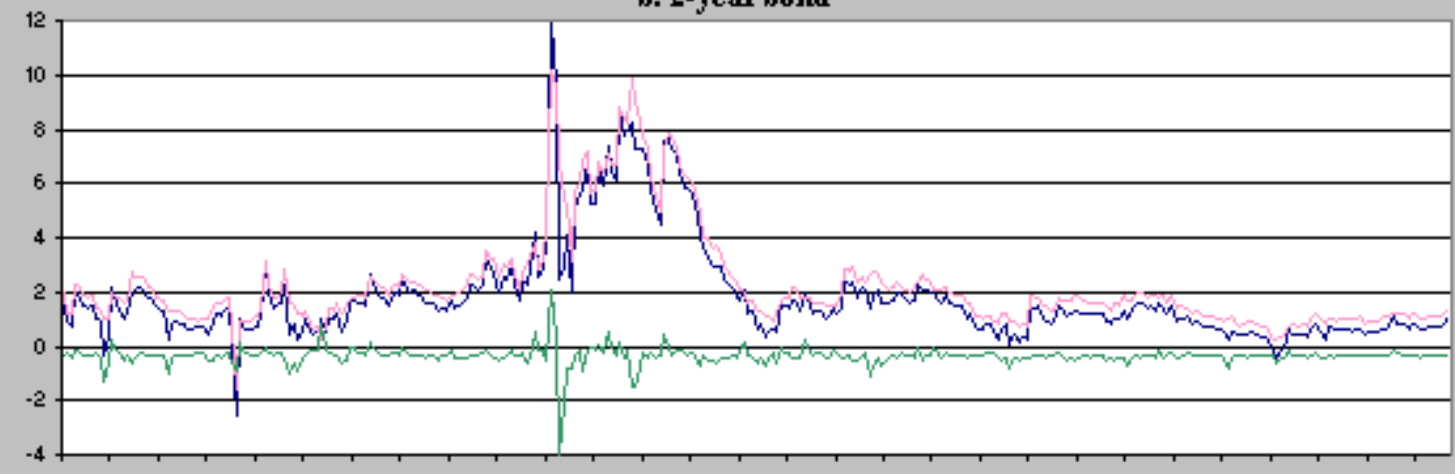

c. 10-year bond

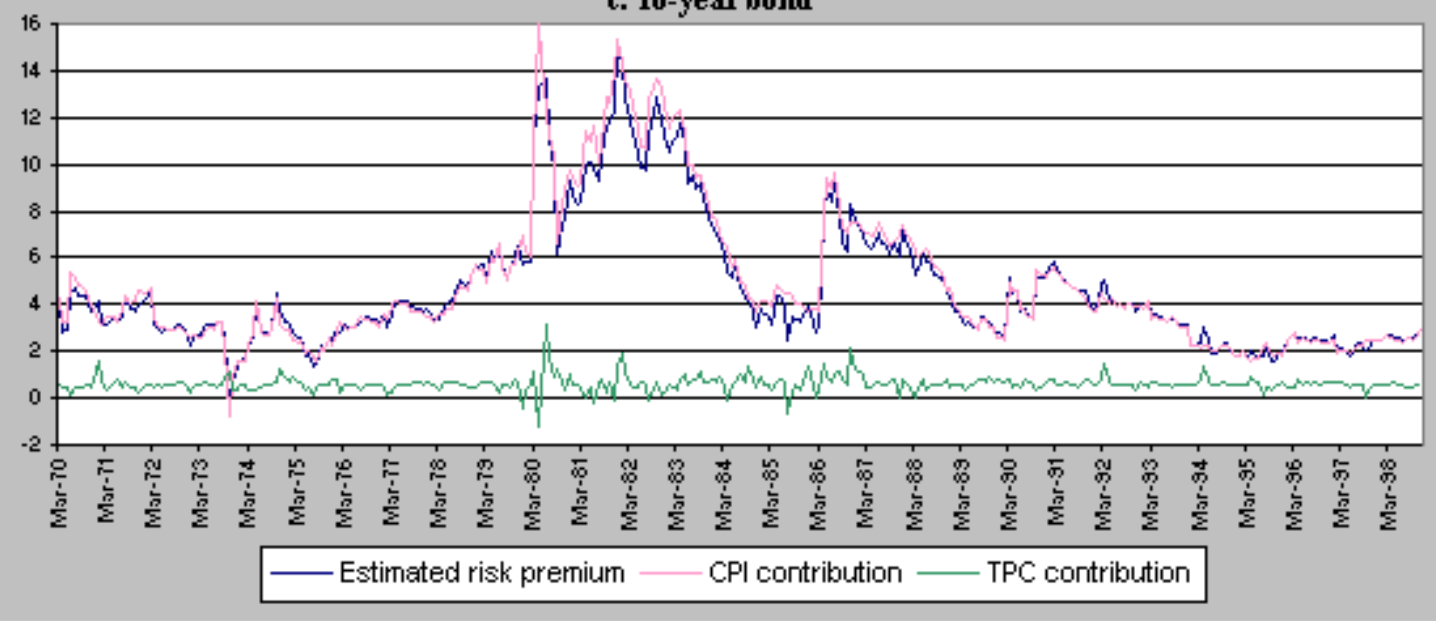


Figure 2: Estimated Risk Premia (including Jensen effect) and Excess Returns
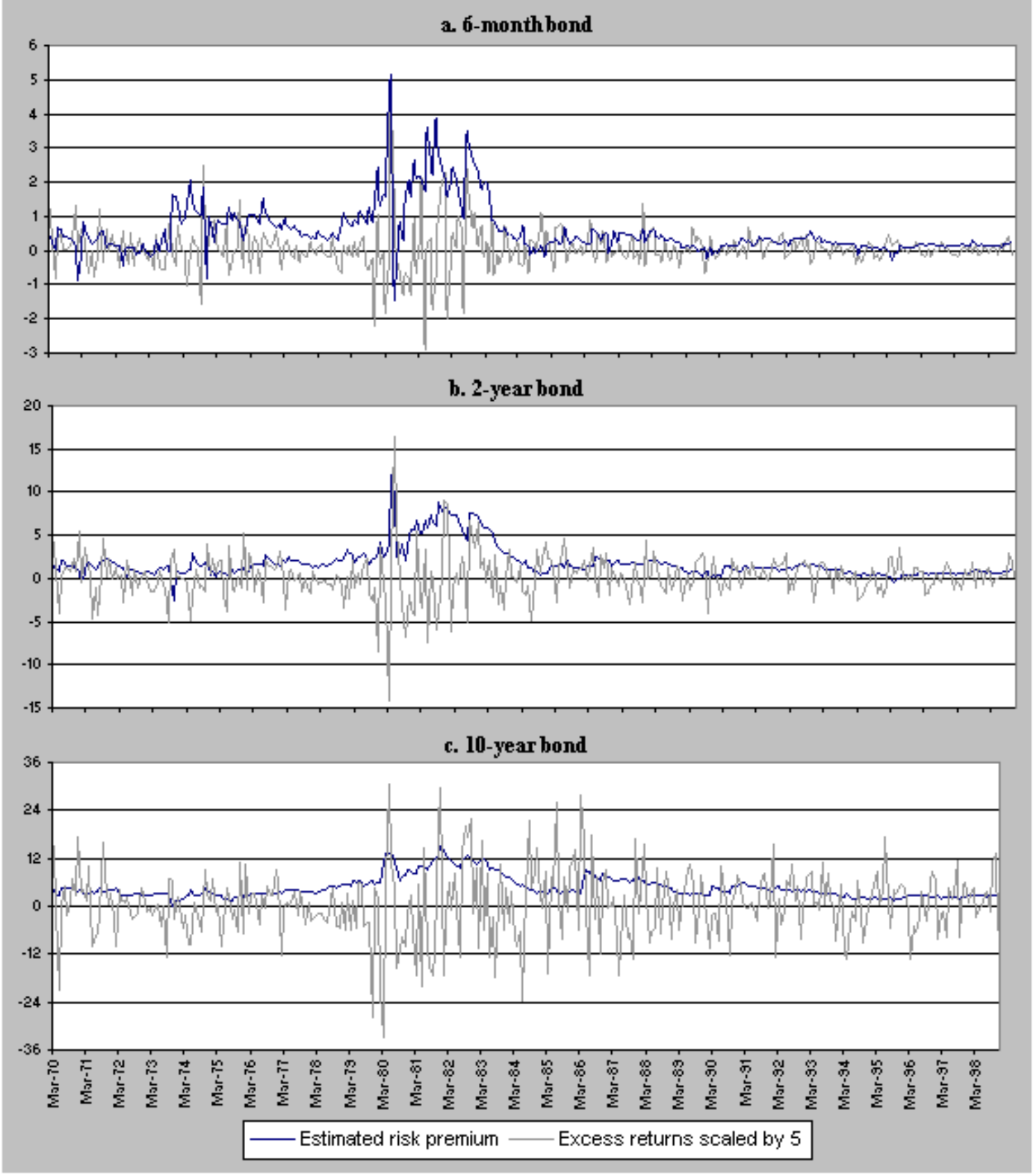
Figure 3: Estimated Risk Premia (including Jensen effect)

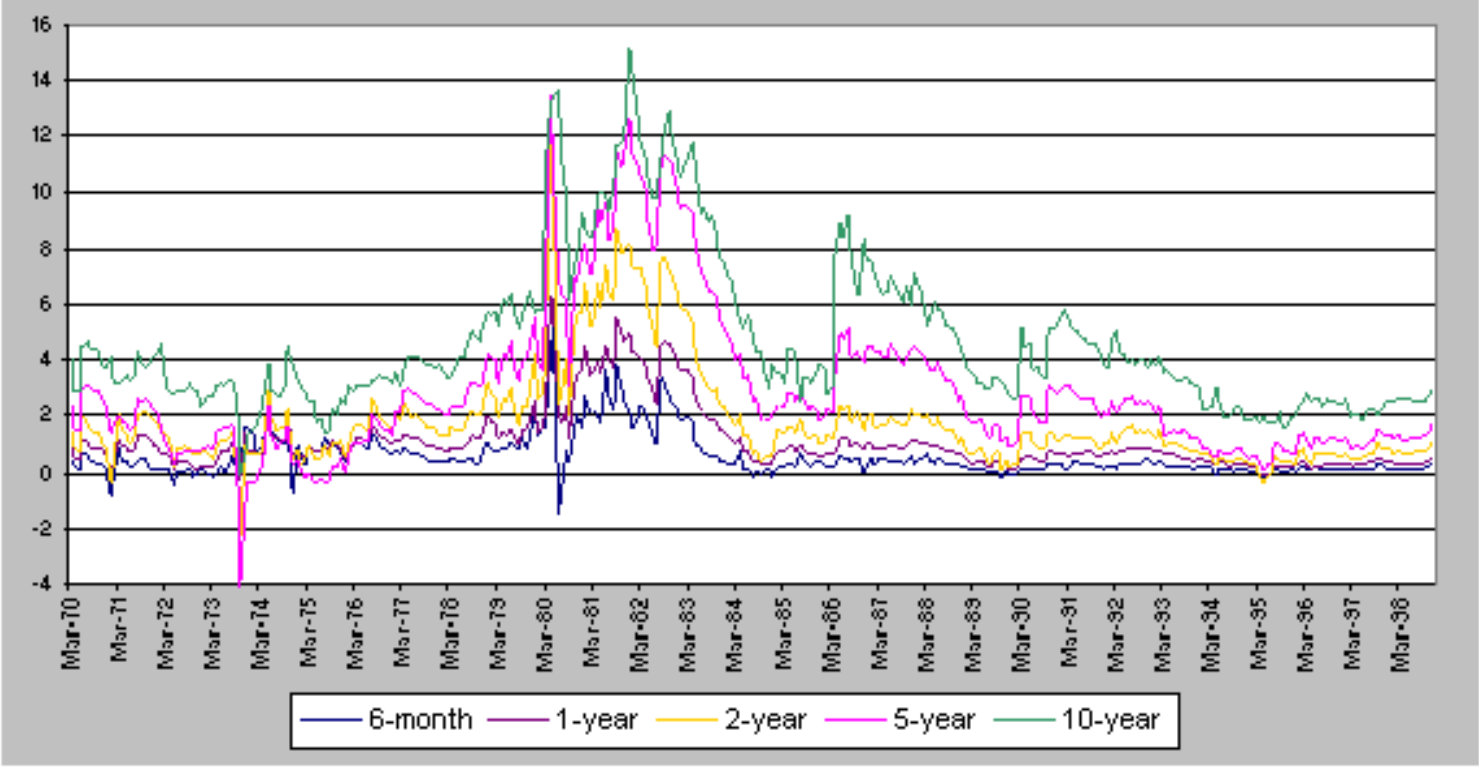

Figure 4: Rolling risk premia in bonds of different maturities Static expectations

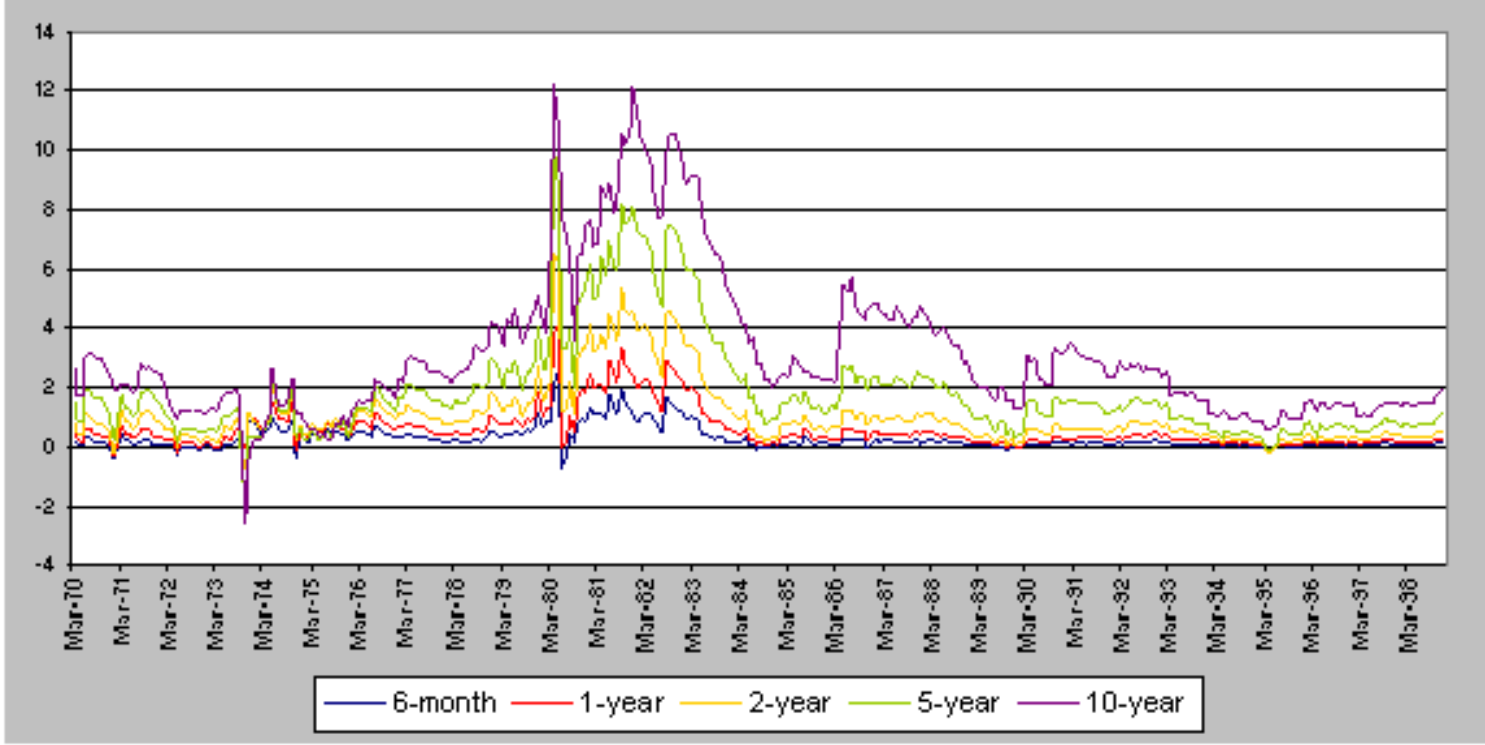


Figure 5: Rolling risk premia in bonds of different maturities Perfect foresight

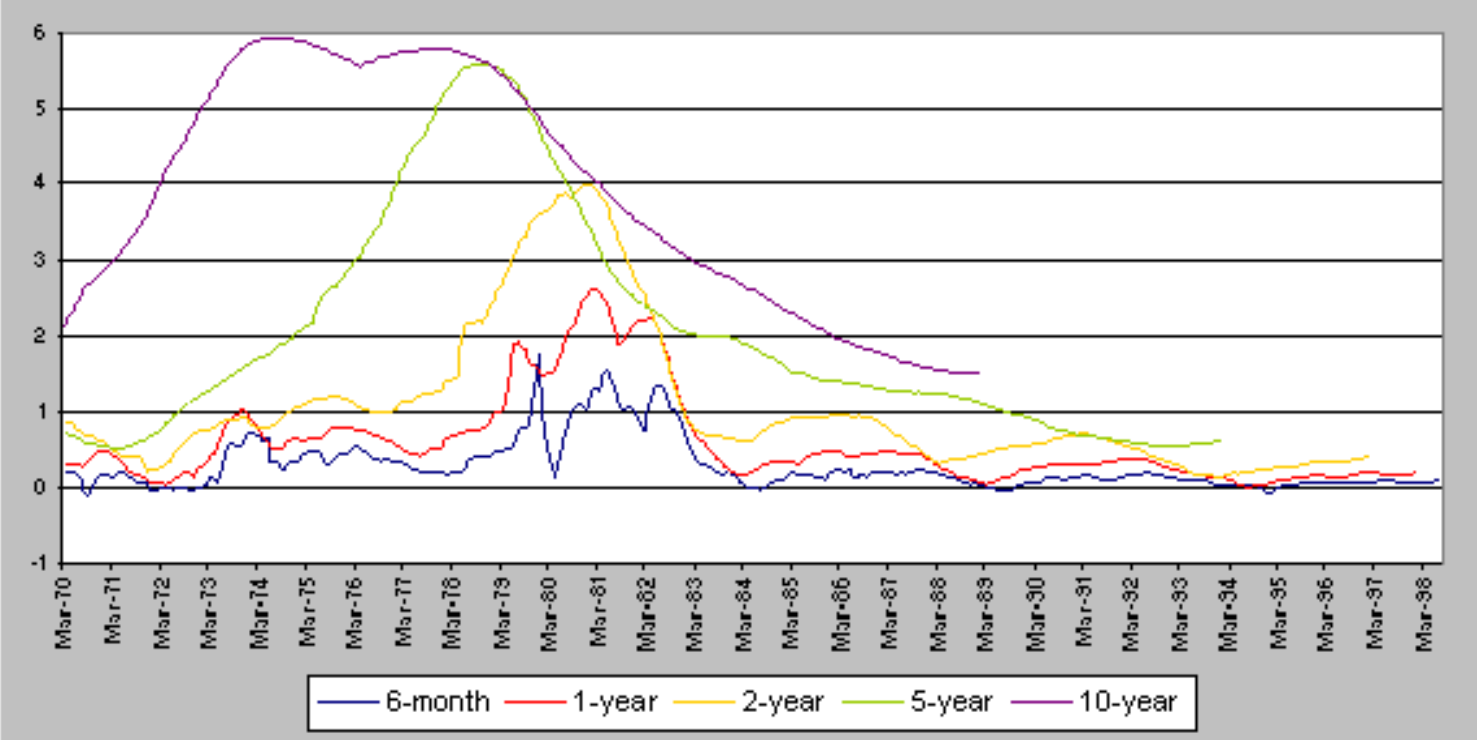

Figure 6: Rolling risk premia in bonds of different maturities as \% of yield Static expectations

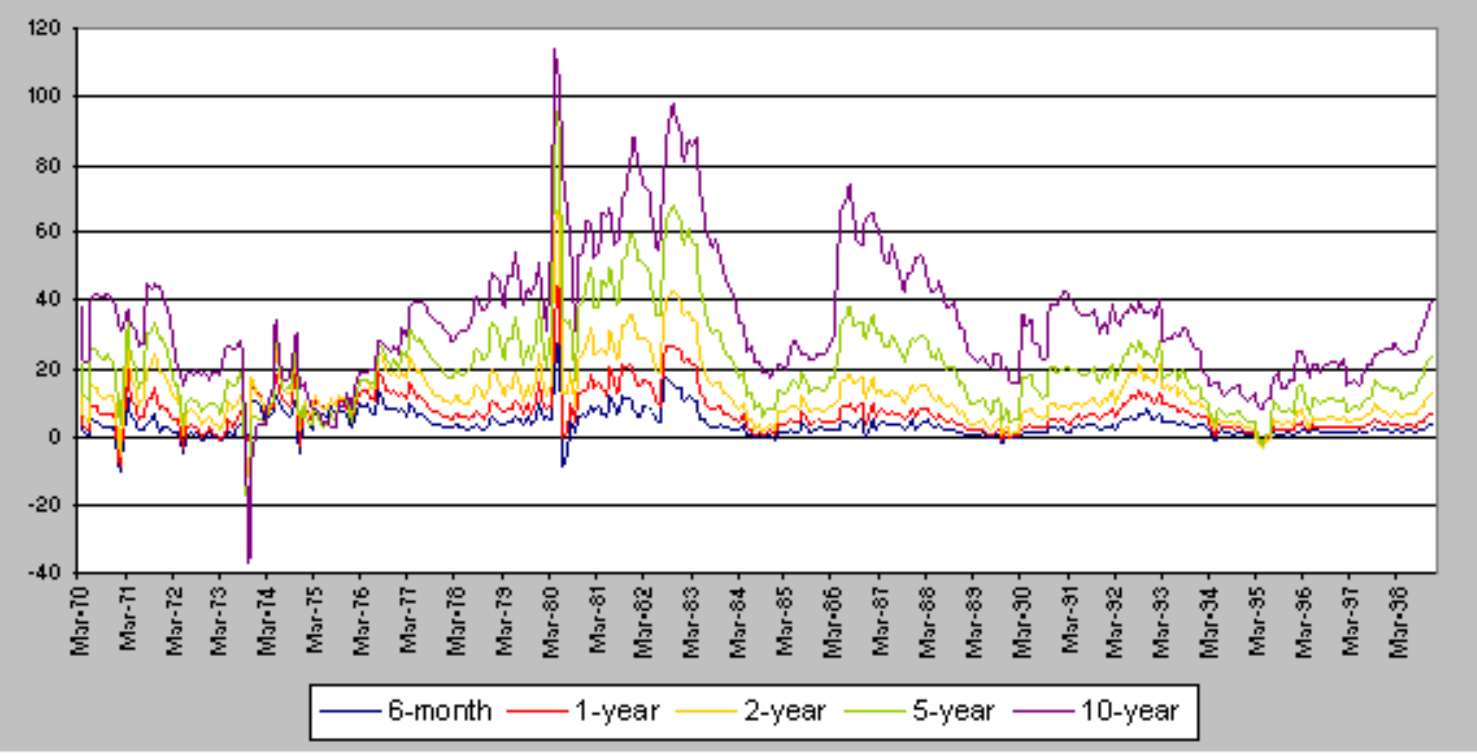




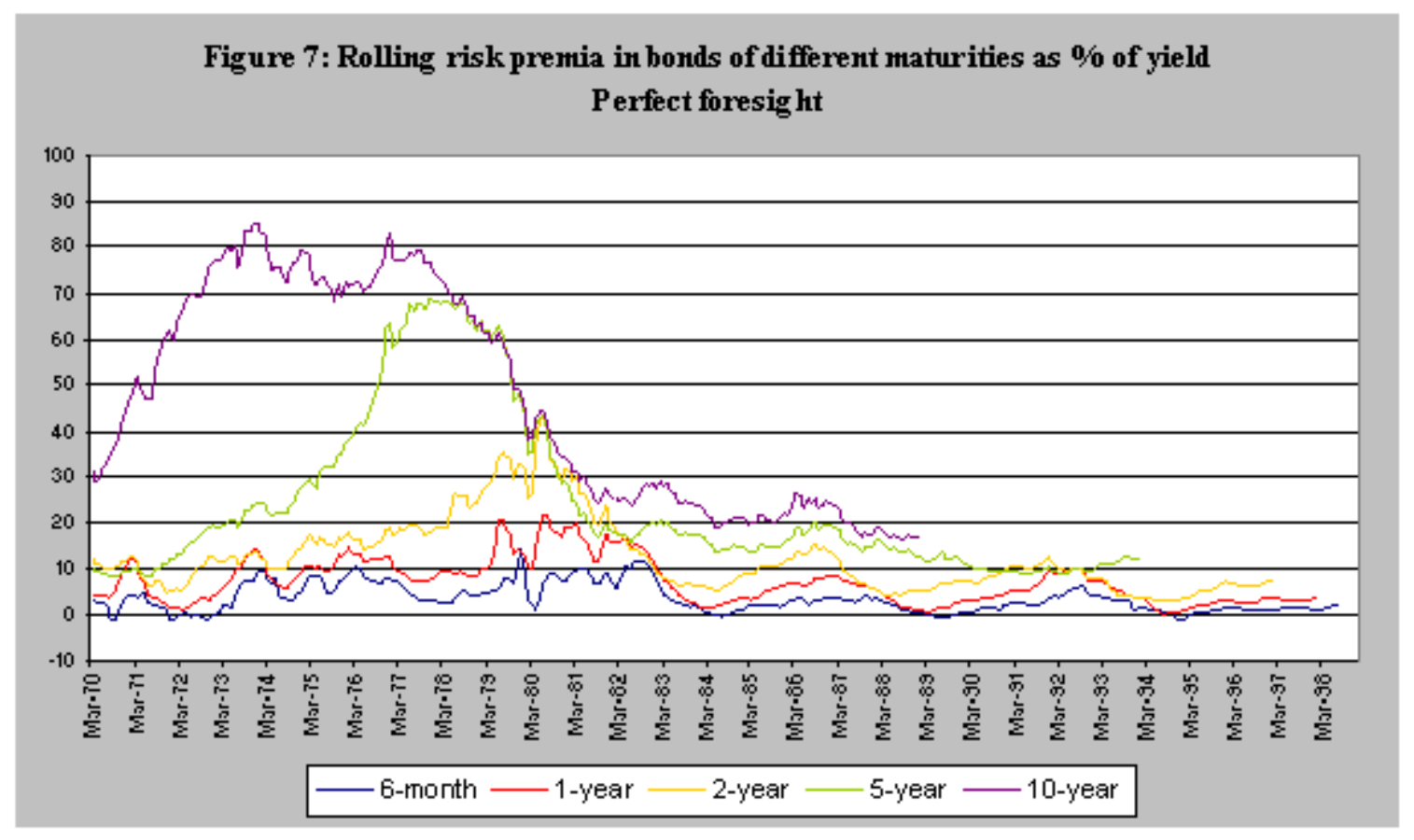




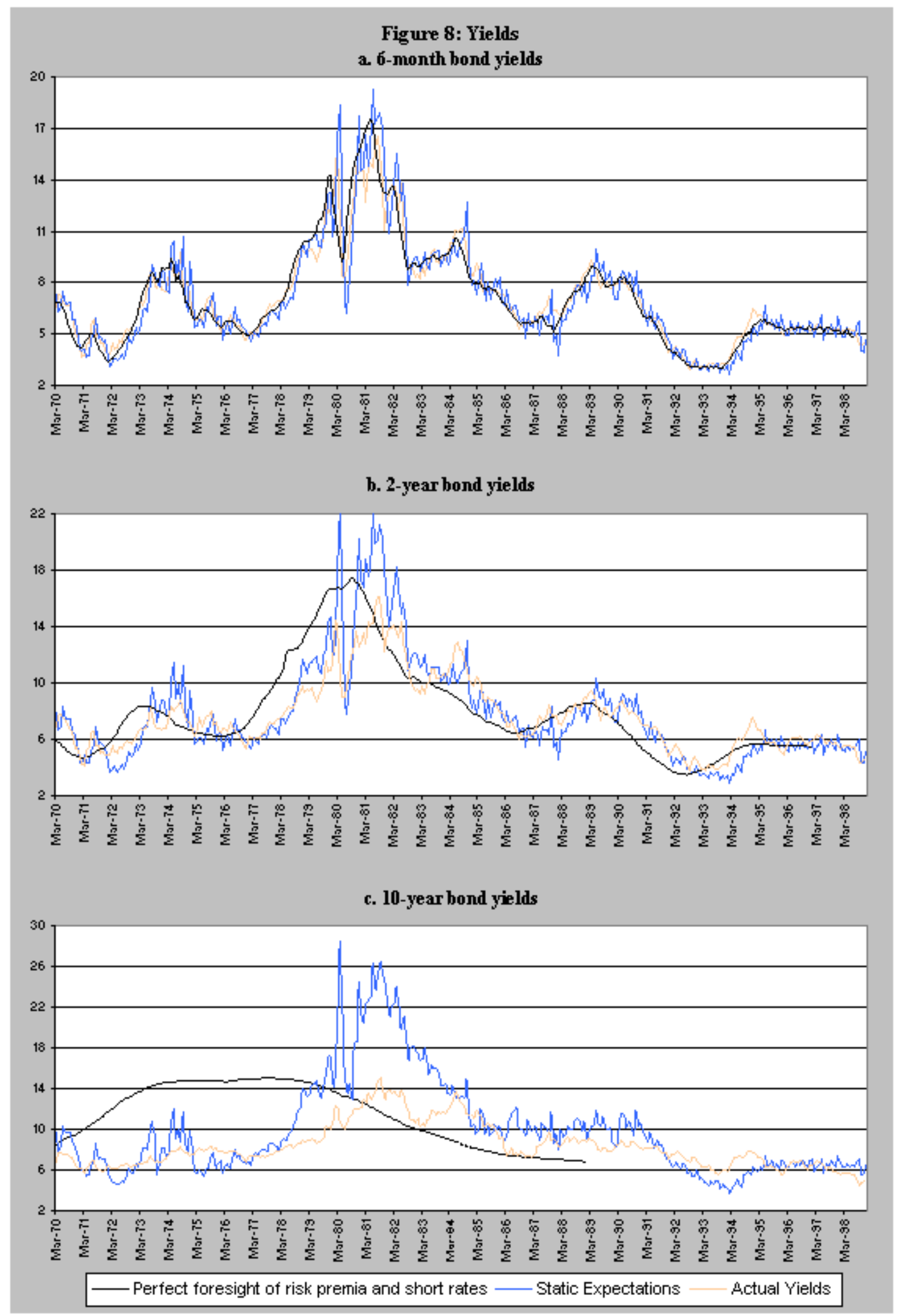


Figure 9: Term Structures

a. Actual Yields

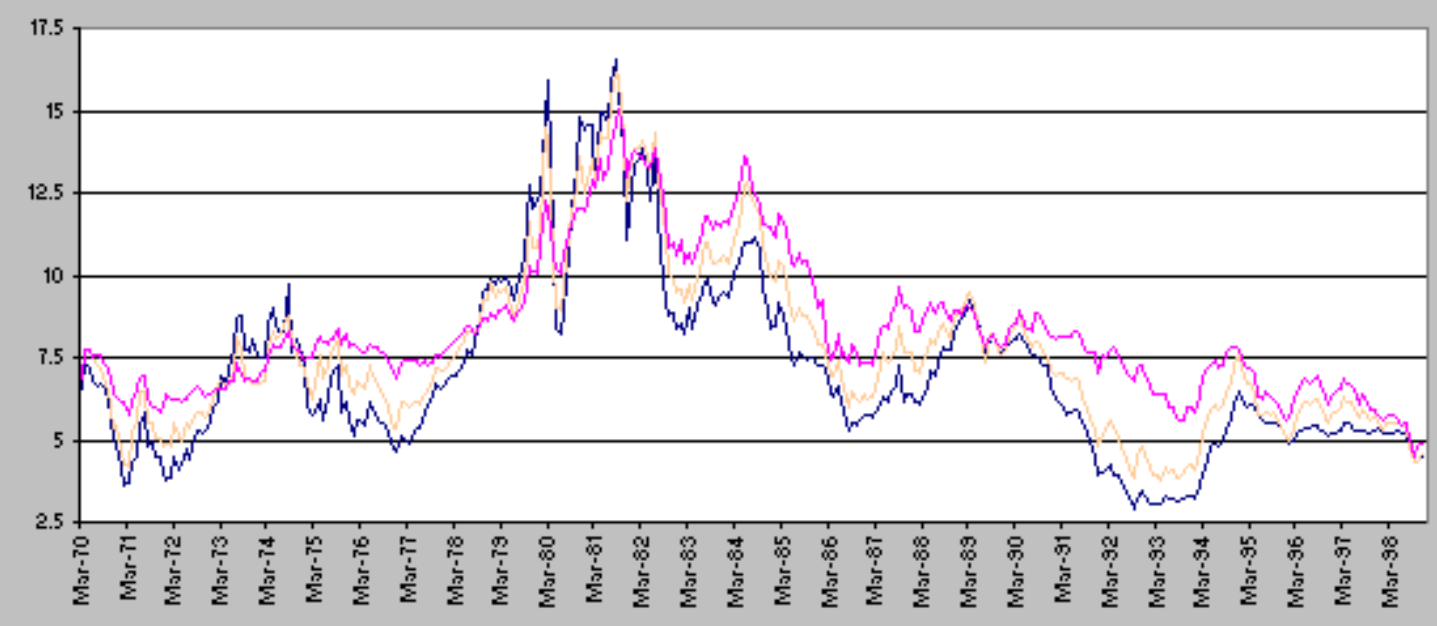

b. Reconstructed Yields - Static expectations of risk premia and short rates

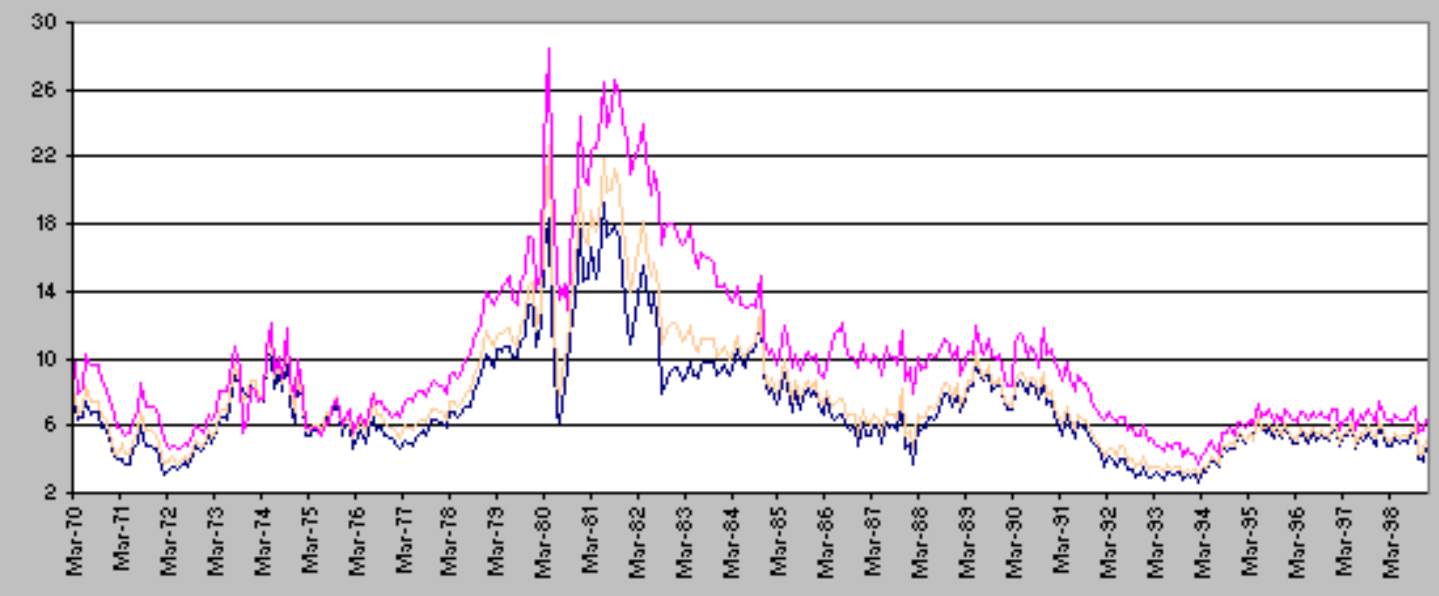

c. Reconstructed Yields - Perfect foresight of risk premia and short rates

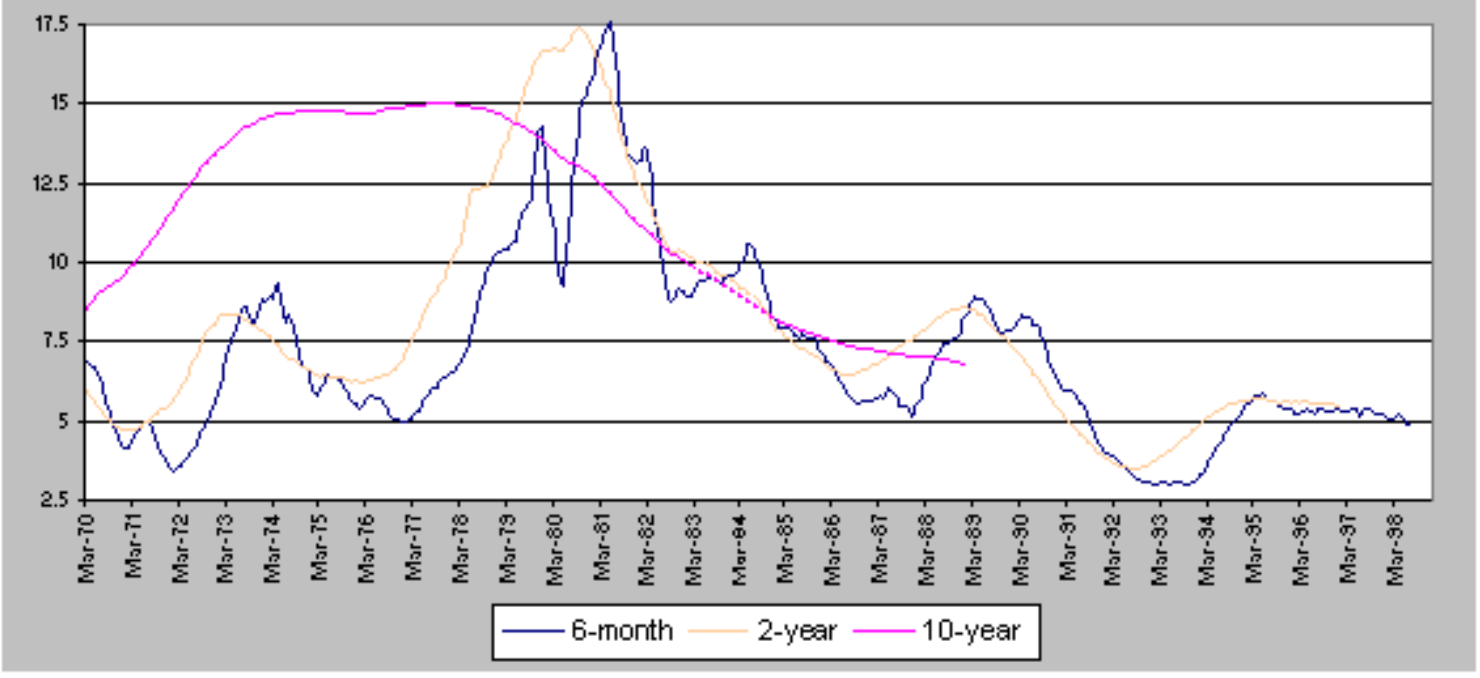




\title{
CESifo Working Paper Series
}

\author{
(for full list see www.cesifo.de)
}

1269 Thomas Eichner and Rüdiger Pethig, Economic Land Use, Ecosystem Services and Microfounded Species Dynamics, September 2004

1270 Federico Revelli, Performance Rating and Yardstick Competition in Social Service Provision, September 2004

1271 Gerhard O. Orosel and Klaus G. Zauner, Vertical Product Differentiation When Quality is Unobservable to Buyers, September 2004

1272 Christoph Böhringer, Stefan Boeters, and Michael Feil, Taxation and Unemployment: An Applied General Equilibrium Approach, September 2004

1273 Assaf Razin and Efraim Sadka, Welfare Migration: Is the Net Fiscal Burden a Good Measure of its Economics Impact on the Welfare of the Native-Born Population?, September 2004

1274 Tomer Blumkin and Volker Grossmann, Ideological Polarization, Sticky Information, and Policy Reforms, September 2004

1275 Katherine Baicker and Nora Gordon, The Effect of Mandated State Education Spending on Total Local Resources, September 2004

1276 Gabriel J. Felbermayr and Wilhelm Kohler, Exploring the Intensive and Extensive Margins of World Trade, September 2004

1277 John Burbidge, Katherine Cuff and John Leach, Capital Tax Competition with Heterogeneous Firms and Agglomeration Effects, September 2004

1278 Joern-Steffen Pischke, Labor Market Institutions, Wages and Investment, September 2004

1279 Josef Falkinger and Volker Grossmann, Institutions and Development: The Interaction between Trade Regime and Political System, September 2004

1280 Paolo Surico, Inflation Targeting and Nonlinear Policy Rules: The Case of Asymmetric Preferences, September 2004

1281 Ayal Kimhi, Growth, Inequality and Labor Markets in LDCs: A Survey, September 2004

1282 Robert Dur and Amihai Glazer, Optimal Incentive Contracts for a Worker who Envies his Boss, September 2004

1283 Klaus Abberger, Nonparametric Regression and the Detection of Turning Points in the Ifo Business Climate, September 2004 
1284 Werner Güth and Rupert Sausgruber, Tax Morale and Optimal Taxation, September 2004

1285 Luis H. R. Alvarez and Erkki Koskela, Does Risk Aversion Accelerate Optimal Forest Rotation under Uncertainty?, September 2004

1286 Giorgio Brunello and Maria De Paola, Market Failures and the Under-Provision of Training, September 2004

1287 Sanjeev Goyal, Marco van der Leij and José Luis Moraga-González, Economics: An Emerging Small World?, September 2004

1288 Sandro Maffei, Nikolai Raabe and Heinrich W. Ursprung, Political Repression and Child Labor: Theory and Empirical Evidence, September 2004

1289 Georg Götz and Klaus Gugler, Market Concentration and Product Variety under Spatial Competition: Evidence from Retail Gasoline, September 2004

1290 Jonathan Temple and Ludger Wößmann, Dualism and Cross-Country Growth Regressions, September 2004

1291 Ravi Kanbur, Jukka Pirttilä and Matti Tuomala, Non-Welfarist Optimal Taxation and Behavioral Public Economics, October 2004

1292 Maarten C. W. Janssen, José Luis Moraga-González and Matthijs R. Wildenbeest, Consumer Search and Oligopolistic Pricing: An Empirical Investigation, October 2004

1293 Kira Börner and Christa Hainz, The Political Economy of Corruption and the Role of Financial Institutions, October 2004

1294 Christoph A. Schaltegger and Lars P. Feld, Do Large Cabinets Favor Large Governments? Evidence from Swiss Sub-Federal Jurisdictions, October 2004

1295 Marc-Andreas Mündler, The Existence of Informationally Efficient Markets When Individuals Are Rational, October 2004

1296 Hendrik Jürges, Wolfram F. Richter and Kerstin Schneider, Teacher Quality and Incentives: Theoretical and Empirical Effects of Standards on Teacher Quality, October 2004

1297 David S. Evans and Michael Salinger, An Empirical Analysis of Bundling and Tying: Over-the-Counter Pain Relief and Cold Medicines, October 2004

1298 Gershon Ben-Shakhar, Gary Bornstein, Astrid Hopfensitz and Frans van Winden, Reciprocity and Emotions: Arousal, Self-Reports, and Expectations, October 2004

1299 B. Zorina Khan and Kenneth L. Sokoloff, Institutions and Technological Innovation During Early Economic Growth: Evidence from the Great Inventors of the United States, 1790 - 1930, October 2004 
1300 Piero Gottardi and Roberto Serrano, Market Power and Information Revelation in Dynamic Trading, October 2004

1301 Alan V. Deardorff, Who Makes the Rules of Globalization?, October 2004

1302 Sheilagh Ogilvie, The Use and Abuse of Trust: Social Capital and its Deployment by Early Modern Guilds, October 2004

1303 Mario Jametti and Thomas von Ungern-Sternberg, Disaster Insurance or a Disastrous Insurance - Natural Disaster Insurance in France, October 2004

1304 Pieter A. Gautier and José Luis Moraga-González, Strategic Wage Setting and Coordination Frictions with Multiple Applications, October 2004

1305 Julia Darby, Anton Muscatelli and Graeme Roy, Fiscal Federalism, Fiscal Consolidations and Cuts in Central Government Grants: Evidence from an Event Study, October 2004

1306 Michael Waldman, Antitrust Perspectives for Durable-Goods Markets, October 2004

1307 Josef Honerkamp, Stefan Moog and Bernd Raffelhüschen, Earlier or Later: A General Equilibrium Analysis of Bringing Forward an Already Announced Tax Reform, October 2004

1308 M. Hashem Pesaran, A Pair-Wise Approach to Testing for Output and Growth Convergence, October 2004

1309 John Bishop and Ferran Mane, Educational Reform and Disadvantaged Students: Are They Better Off or Worse Off?, October 2004

1310 Alfredo Schclarek, Consumption and Keynesian Fiscal Policy, October 2004

1311 Wolfram F. Richter, Efficiency Effects of Tax Deductions for Work-Related Expenses, October 2004

1312 Franco Mariuzzo, Patrick Paul Walsh and Ciara Whelan, EU Merger Control in Differentiated Product Industries, October 2004

1313 Kurt Schmidheiny, Income Segregation and Local Progressive Taxation: Empirical Evidence from Switzerland, October 2004

1314 David S. Evans, Andrei Hagiu and Richard Schmalensee, A Survey of the Economic Role of Software Platforms in Computer-Based Industries, October 2004

1315 Frank Riedel and Elmar Wolfstetter, Immediate Demand Reduction in Simultaneous Ascending Bid Auctions, October 2004

1316 Patricia Crifo and Jean-Louis Rullière, Incentives and Anonymity Principle: Crowding Out Toward Users, October 2004 
1317 Attila Ambrus and Rossella Argenziano, Network Markets and Consumers Coordination, October 2004

1318 Margarita Katsimi and Thomas Moutos, Monopoly, Inequality and Redistribution Via the Public Provision of Private Goods, October 2004

1319 Jens Josephson and Karl Wärneryd, Long-Run Selection and the Work Ethic, October 2004

1320 Jan K. Brueckner and Oleg Smirnov, Workings of the Melting Pot: Social Networks and the Evolution of Population Attributes, October 2004

1321 Thomas Fuchs and Ludger Wößmann, Computers and Student Learning: Bivariate and Multivariate Evidence on the Availability and Use of Computers at Home and at School, November 2004

1322 Alberto Bisin, Piero Gottardi and Adriano A. Rampini, Managerial Hedging and Portfolio Monitoring, November 2004

1323 Cecilia García-Peñalosa and Jean-François Wen, Redistribution and Occupational Choice in a Schumpeterian Growth Model, November 2004

1324 William Martin and Robert Rowthorn, Will Stability Last?, November 2004

1325 Jianpei Li and Elmar Wolfstetter, Partnership Dissolution, Complementarity, and Investment Incentives, November 2004

1326 Hans Fehr, Sabine Jokisch and Laurence J. Kotlikoff, Fertility, Mortality, and the Developed World's Demographic Transition, November 2004

1327 Adam Elbourne and Jakob de Haan, Asymmetric Monetary Transmission in EMU: The Robustness of VAR Conclusions and Cecchetti's Legal Family Theory, November 2004

1328 Karel-Jan Alsem, Steven Brakman, Lex Hoogduin and Gerard Kuper, The Impact of Newspapers on Consumer Confidence: Does Spin Bias Exist?, November 2004

1329 Chiona Balfoussia and Mike Wickens, Macroeconomic Sources of Risk in the Term Structure, November 2004 